\title{
Variations of soil profile characteristics due to varying time spans since ice retreat in the inner Nordfjord, western Norway
}

\author{
A. Navas ${ }^{1}$, K. Laute ${ }^{2}$, A. A. Beylich ${ }^{2}$, and L. Gaspar ${ }^{3}$ \\ ${ }^{1}$ Estación Experimental de Aula Dei (EEAD-CSIC), Department of Soil and Water, Avda. Montañana 1005, \\ 50059 Zaragoza, Spain \\ ${ }^{2}$ Geological Survey of Norway (NGU), Geo-Environment Division, 7491 Trondheim, Norway \\ ${ }^{3}$ School of Geography, Earth and Environmental Sciences, Plymouth University, Plymouth, Devon, PL4 8AA, UK \\ Correspondence to: A. Navas (anavas@eead.csic.es)
}

Received: 8 December 2013 - Published in Solid Earth Discuss.: 10 January 2014

Revised: 1 April 2014 - Accepted: 20 April 2014 - Published: 11 June 2014

\begin{abstract}
In the Erdalen and Bødalen drainage basins located in the inner Nordfjord in western Norway the soils were formed after deglaciation. The climate in the uppermost valley areas is sub-arctic oceanic, and the lithology consists of Precambrian granitic orthogneisses on which Leptosols and Regosols are the most common soils. The Little Ice Age glacier advance affected parts of the valleys with the maximum glacier extent around AD 1750. In this study five sites on moraine and colluvium materials were selected to examine main soil properties, grain size distribution, soil organic carbon and $\mathrm{pH}$ to assess if soil profile characteristics and patterns of fallout radionuclides (FRNs) and environmental radionuclides (ERNs) are affected by different stages of ice retreat. The Leptosols on the moraines are shallow, poorly developed and vegetated with moss and small birches. The two selected profiles show different radionuclide activities and grain size distribution. The sampled soils on the colluviums outside the LIA glacier limit became ice-free during the Preboral. The Regosols present better-developed profiles, thicker organic horizons and are fully covered by grasses. Activity of ${ }^{137} \mathrm{Cs}$ and ${ }^{210} \mathrm{~Pb}_{\mathrm{ex}}$ concentrate at the topsoil and decrease sharply with depth. The grain size distribution of these soils also reflects the difference in geomorphic processes that have affected the colluvium sites. Significantly lower mass activities of FRNs were found in soils on the moraines than on colluviums. Variations of ERN activities in the valleys were related to characteristics of soil mineralogical composition. These results indicate differences in soil development that are consistent with the age of ice retreat. In addition, the pattern distribution of ${ }^{137} \mathrm{Cs}$ and ${ }^{210} \mathrm{~Pb}_{\mathrm{ex}}$ activi-
\end{abstract}

ties differs in the soils related to the LIA glacier limits in the drainage basins.

\section{Introduction}

Glacial retreat in the cold regions of Northern Europe is a general trend that has intensified over the last decades. In the Nordfjord region (western Norway) this trend is also observed and the magnitude of glacial retreat in the Erdalen and $\mathrm{B} \emptyset$ dalen valleys has reached its fastest rate over the last century in recent years (e.g. Winkler et al., 2009; Laute and Beylich, 2013). The retreat of ice from glaciated valleys (Mavlyudov et al., 2012) causes important changes in geomorphic processes of glacial erosion, but also has an impact on the hydrological resources by changing runoff and associated sediment transport as well as on the formation of soils on the newly exposed surfaces.

The landscapes of Norwegian fjords reveal the inheritance of glacial processes since the Last Glacial Maximum (LGM). The Little Ice Age (LIA) glacier advance also affected parts of the Norwegian valleys (Bickerton and Matthews, 1993; Laute and Beylich, 2012, 2013). Amongst the main glacial deposits colluviums and moraines are surface formations resulting from the evolution of slopes and the ice retreat. In the glacial valleys these formations are representative of newly exposed material conditioned by former glaciations and deglaciation. Moraine ridges formed during and after the maximum extent of the Little Ice Age (LIA) with the maximum glacier extent around AD 1750 (Bickerton and 


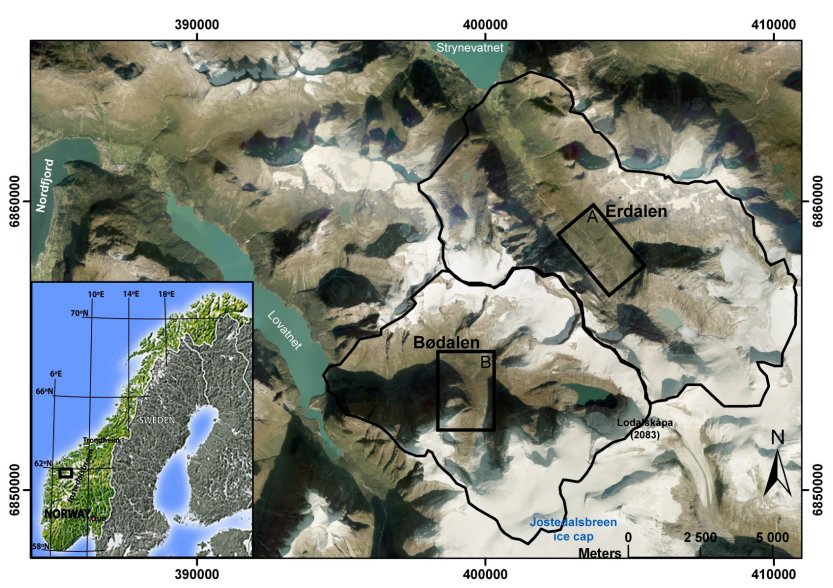

Figure 1. Location of the Nordfjord region (western Norway), aerial photograph of the Erdalen and Bødalen glacial valleys and situation of the study areas.

Matthews, 1993). The soils have been forming on the newly exposed glacial deposits, and as a result of processes related to ice retreat, different soil types have developed. Soil properties might be characteristic of materials and processes and could reflect different ages of ice retreat. In this study we aim to characterize the soils formed on colluvium and moraine material. We applied a multiproxy approach in order to examine if the soil elemental composition ( $\mathrm{Li}, \mathrm{K}, \mathrm{Na}, \mathrm{Be}, \mathrm{Mg}$, $\mathrm{Ca}, \mathrm{Sr}, \mathrm{Cr}, \mathrm{Cu}, \mathrm{Mn}, \mathrm{Fe}, \mathrm{Al}, \mathrm{Zn}, \mathrm{Ni}, \mathrm{Co}, \mathrm{Cd}, \mathrm{Tl}, \mathrm{Bi}, \mathrm{V}, \mathrm{Ti}$, $\mathrm{Pb}, \mathrm{B}, \mathrm{Sb}, \mathrm{As}, \mathrm{P}, \mathrm{S}, \mathrm{Mo}$ and $\mathrm{Se}$ ) and radionuclide tracers, environmental (ERNs: ${ }^{238} \mathrm{U},{ }^{210} \mathrm{~Pb},{ }^{226} \mathrm{Ra},{ }^{232} \mathrm{Th},{ }^{40} \mathrm{~K},{ }^{210} \mathrm{~Pb}$ ) and fallout (FRNs: ${ }^{137} \mathrm{Cs}$ and ${ }^{210} \mathrm{~Pb}_{\mathrm{ex}}$ ), together with other properties (grain size distribution, soil organic carbon, $\mathrm{pH}$ ) could be indicative of soil development, and if it was related to stages of ice retreat. To this purpose we selected two glacial valleys representative of the inner Nordfjord region, the valleys of Erdalen and Bødalen, and sampled five sites on two main geomorphic elements, moraine and colluvium, to examine within the soil profile main soil properties, elemental composition and fallout (FRNs) and environmental radionuclides (ERNs).

\section{Material and methods}

\subsection{The study area}

The inner Nordfjord region is located in western Norway on the western side of the Jostedalsbreen ice cap (Fig. 1). Climate is sub-arctic oceanic in the uppermost parts of tributary valleys draining into the fjord. The mean annual air temperature at $360 \mathrm{~m}$ a.s.l. is $5.5^{\circ} \mathrm{C}$ and the mean annual areal precipitation is $1500 \mathrm{~mm}$ in the drainage basins of Erdalen and Bødalen (Table 1) (Beylich and Laute, 2012; Laute and Beylich, 2014).

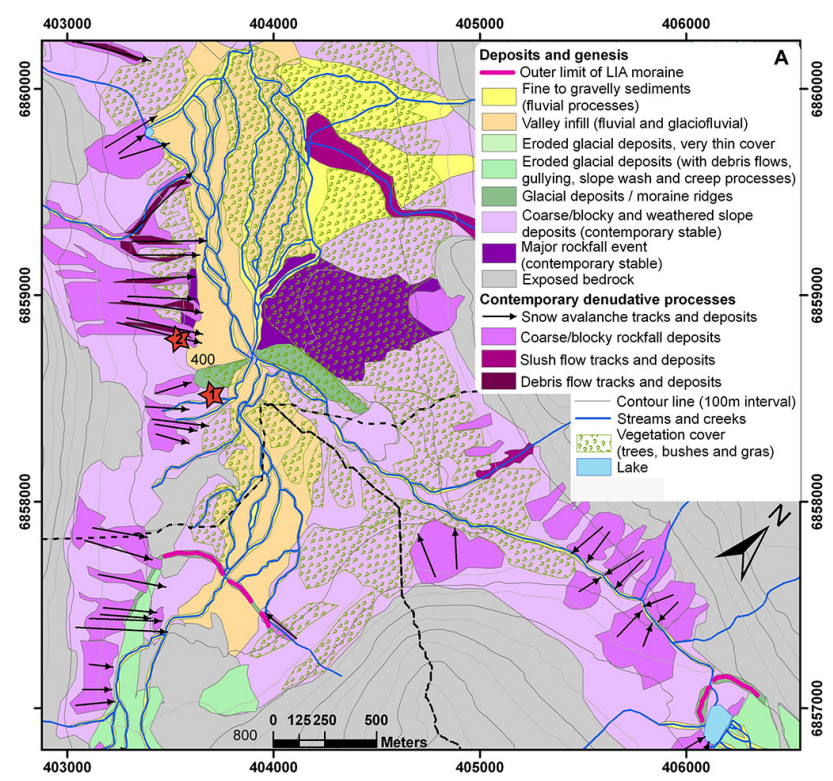

Figure 2. Geomorphological map of the Erdalen drainage basin (modified after Laute and Beylich, 2012) and location of the study profiles 1) PE1 and 2) PE2.

The lithology in the valleys consists of Precambrian granitic orthogneisses with migmatic and dioritic composition (Table 1). Within the higher part in Bødalen (glacier area) there is a small area of quartz monzonite outcrops (Lutro and Tveten, 1996).

The landforms and processes in the study area are characteristic of glacial valleys. The detailed geomorphological maps (Laute and Beylich, 2012) shown in Figs. 2 and 3 present the main deposits identified in the valleys and their genesis. The main contemporary denudational surface processes, the limits of the LIA moraines and the soil profiles studied are identified in the maps.

Based on intensive field pre-investigations and existing knowledge, sites which are representative for the relevant deposits existing in the valleys and which are close to defined and dated moraine ridges were considered for this preliminary study. Furthermore, an important criterion for the selection was that the sampling sites were nearly horizontal, and no relevant delivery of new material was currently affecting these sites. A total of five sites corresponding to soils developed on moraine and colluvium deposits, the most common formations of the glacier valleys and which represent different stages of ice retreat, were selected for collecting soil profiles. Two profiles were established on moraines in the $B \varnothing$ dalen valley (PB1 and PB2) and the other three profiles were established on colluvium materials in the Erdalen (PE1, PE2) and Bødalen (PB3) valleys. The profiles on the moraines are located inside the LIA glacier limit; the moraine material is in general characterized by diamicton. The two sites represent different stages of ice retreat, thus PB1 became ice-free starting from ca. AD 1930, but PB2 became ice-free earlier, 
Table 1. Physiographic and climatic characteristics of the drainage basins of Erdalen and Bødalen (Nordfjord region, Norway).

\begin{tabular}{|c|c|c|}
\hline & Erdalen & Bødalen \\
\hline Geographical coordinates & $61^{\circ} 50^{\prime} \mathrm{N}, 07^{\circ} 10^{\prime} \mathrm{E}$ & $61^{\circ} 48^{\prime} \mathrm{N}, 07^{\circ} 05^{\prime} \mathrm{E}$ \\
\hline Drainage basin area $\left[\mathrm{km}^{2}\right]$ & 79.5 & 60.1 \\
\hline Elevation min [m a.s.1.] & 20 & 52 \\
\hline Elevation max [m a.s.1.] & 1888 & 2083 \\
\hline Relief $[\mathrm{m}]$ & 1868 & 2031 \\
\hline Mean slope $\left[{ }^{\circ}\right]$ & 32 & 34 \\
\hline Lithology & \multicolumn{2}{|c|}{ Precambrian granitic orthogneisses } \\
\hline Dominant soils & \multicolumn{2}{|c|}{ Leptosols, Regosols } \\
\hline Vegetation & \multicolumn{2}{|c|}{ Birch, grey alder, grass, moos, lichens } \\
\hline Annual precipitation [mm] (at $360 \mathrm{~m}$ a.s.1.) & 1500 & 1500 \\
\hline Mean annual air temperature $\left[{ }^{\circ} \mathrm{C}\right]$ (at $360 \mathrm{~m}$ a.s.1.) & 5.5 & 5.5 \\
\hline \multicolumn{3}{|l|}{ Surface area percentages ${ }^{\mathrm{a}}[\%]$} \\
\hline Glacier & 18 & 38 \\
\hline Bedrock & 45 & 43 \\
\hline Slope deposits/regolith & 32 & 16 \\
\hline Valley infill & 5 & 2 \\
\hline Lake & $<1$ & 1 \\
\hline
\end{tabular}

a As \% of the total drainage basin surface area.

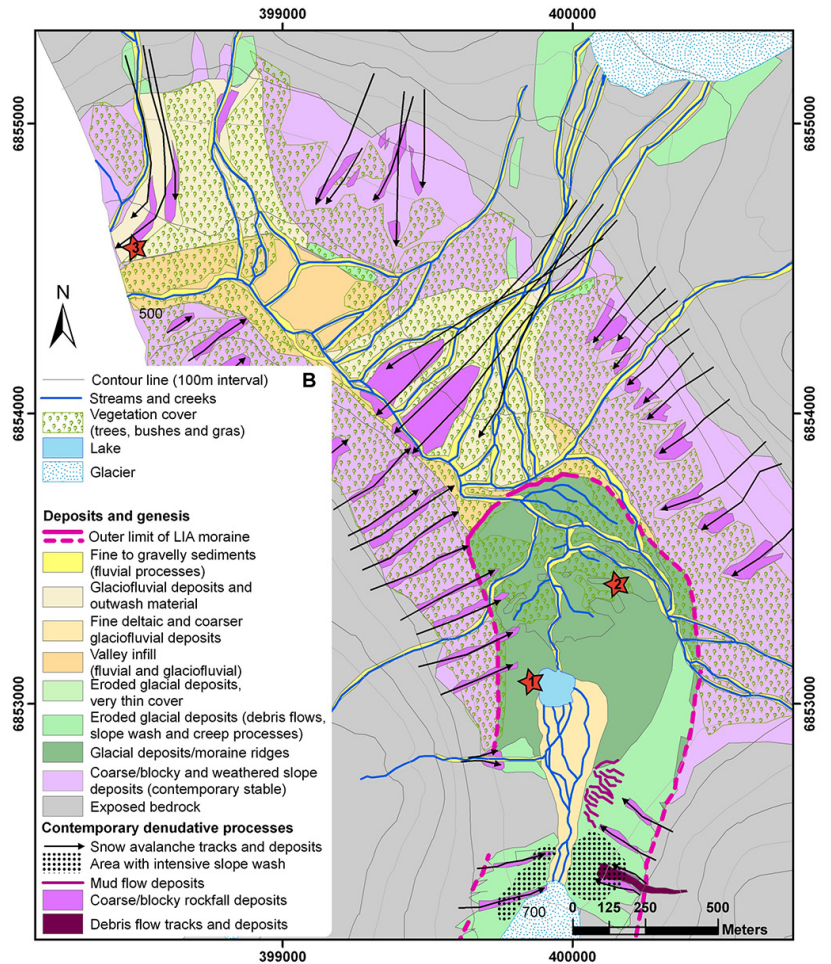

Figure 3. Geomorphological map of the Bødalen drainage basin (modified after Laute and Beylich, 2012) and location of the study profiles 1) PB1, 2) PB2 and 3) PB3.

at about AD 1800 (see Bickerton and Matthews, 1993). Both sites have a vegetation cover composed of mosses and small birches and can be considered quite stable regarding surface soil processes, as they are on gentle slopes. The soils on the moraines are Leptosols (FAO classification); they are poorly developed with almost no horizon differentiation and with a high content of rock fragments.

The colluvium sites, located outside the LIA glacier limit, are characterized by slope processes accumulating both fine and coarser material at the slope foot derived from slope wash, avalanches, debris flows and rock falls. The soils correspond to Regosols that are deeper and better developed than soils on the moraines and those covered by grass. The sites became ice-free during the Preboral deglaciation. Considering the age of ice retreat, the oldest is PB3 in Bødalen, which became ice-free around 10000 years ago. This profile, located on a hillslope beneath the Tindefjell glacier, is more influenced by glaciofluvial and outwash processes rather than rockfall activity and presents high avalanche activity. Of the studied sites PB3 had the strongest anthropogenic impact through animal husbandry, as sheep grazing occurred starting from approximately 1800 , albeit with less intensity since 1930 (T. Lopez, personal communication, 2011). Of the profiles in Erdalen, PE4 had higher rockfall activity and became ice-free earlier than PE3, which had not been ice-free since ca. 9800 BP (see Nesje, 1984; Matthews et al., 2008).

\subsection{Soil sampling and analyses}

To collect the soil samples of the soil profiles, five pits of $20 \times 20 \mathrm{~cm}$ were excavated down to a depth of $20-27 \mathrm{~cm}$. Samples were extracted at depth intervals of approx. 5-6 cm by using a $5 \mathrm{~cm}$ diameter cylinder. Soils in the study area are shallow and according to field observations depths vary from 
few centimetres for Leptosols to a range of 30 to $50 \mathrm{~cm}$ for Regosols.

The soil samples were air-dried, ground, homogenized and quartered to pass through a $2 \mathrm{~mm}$ sieve. The grain size fraction $>2 \mathrm{~mm}$ containing stones and rock fragments was separated and weighted to estimate the percentages of coarse fractions in the soil profiles. General soil properties analysed in the fraction $<2 \mathrm{~mm}$ were $\mathrm{pH}$, soil organic carbon (SOC \%) at $310^{\circ}$ (active carbon fraction, $\mathrm{ACF}$ ) and $550^{\circ}$ (stable carbon fraction, SCF) and soil texture. Analysis of the clay, silt and sand fractions was performed using a laser diffraction particle size analyser. Prior to the analysis the organic matter was eliminated with $\mathrm{H} 2 \mathrm{O} 2(10 \%)$ heated to $80^{\circ} \mathrm{C}$ and samples were disaggregated with sodium hexametaphosphate (40\%), stirred for $2 \mathrm{~h}$ and dispersed with ultrasound for a few minutes. The $\mathrm{pH}(1: 2.5$, soil : water) was measured using a $\mathrm{pH}$ meter.

The contents of SOC, both active and stable carbon fractions, were analysed by the dry combustion method using a LECO $R C$-612 multiphase carbon analyser designed to differentiate forms of carbon by oxidation temperature (LECO, 1996) in a sub-sample of the $<2 \mathrm{~mm}$ fraction that had been ground to a very fine powder with a mortar and pestle. According to López-Capel et al. (2008), the decomposition of the most thermally labile components of SOC is released at approximately $300-350^{\circ} \mathrm{C}$ during thermal decomposition because they are rapidly and easily burnable; the active and decomposable fraction (ACF), while decomposition of more refractory and stable carbon (SCF), occurs at higher temperatures $\left(420-550^{\circ} \mathrm{C}\right)$.

The analysis of the total elemental composition was carried out after total acid digestion with $\mathrm{HF}(48 \%)$ in a microwave oven (Navas et al., 2002c). Samples were analysed for the following 28 elements: Lithium (Li), Potassium (K), Sodium (Na) (alkaline), Beryllium (Be), Magnesium (Mg), Calcium (Ca), Strontium ( $\mathrm{Sr}$ ) (light metals), Chromium (Cr), Copper (Cu), Manganese (Mn), Iron (Fe), Aluminum (Al), Zinc (Zn), Nickel (Ni), Cobalt (Co), Cadmium $(\mathrm{Cd})$, Thallium $(\mathrm{Tl})$, Bismuth $(\mathrm{Bi})$, Vanadium $(\mathrm{V})$, Titanium (Ti) and Lead ( $\mathrm{Pb}$ ) (heavy metals), Boron (B), Antimony ( $\mathrm{Sb}$ ), Arsenic (As) (metalloids), and Phosphorus (P), Sulfur (S), Molybdenum (Mo) and Selenium (Se). Analyses were performed by atomic emission spectrometry using inductively coupled plasma ICP. Concentrations, obtained after three measurements per element, are expressed in $\mathrm{m} \mathrm{kg}^{-1}$.

The methods used in the analysis of radionuclides are described in detail in previous works (Navas et al., 2005a, b). Radionuclide activity in the soil samples was measured using a Canberra high-resolution, low-background, hyperpure germanium coaxial gamma detector coupled to an amplifier and multichannel analyser. The detector had a relative efficiency of $50 \%$ and a resolution of $1.9 \mathrm{keV}$ (shielded to reduce background), and was calibrated using standard certified samples that had the same geometry as the measured samples. Subsamples of $50 \mathrm{~g}$ were loaded into plastic containers. Count times over $24 \mathrm{~h}$ provided an analytical precision of about \pm 3 $10 \%$ at the $95 \%$ confidence level. Activities were expressed as $\mathrm{Bq} \mathrm{kg}^{-1}$ dry soil.

Gamma emissions of Uranium-238 $\left({ }^{238} \mathrm{U}\right)$, Radium-226 $\left({ }^{226} \mathrm{Ra}\right)$, Thorium-232 $\left({ }^{232} \mathrm{Th}\right)$, Potassium-40 $\left({ }^{40} \mathrm{~K}\right)$, Lead$210\left({ }^{210} \mathrm{~Pb}\right)$, and Cesium-137 $\left({ }^{137} \mathrm{Cs}\right)$ (in $\mathrm{Bq} \mathrm{kg}^{-1}$ air-dried soil) were measured in the bulk soil samples. Considering the appropriate corrections for laboratory background, ${ }^{238} \mathrm{U}$ was determined from the $63 \mathrm{keV}$ line of ${ }^{234} \mathrm{Th}$ (lower limit of detection (LLD): $2.6 \mathrm{~Bq} \mathrm{~kg}^{-1}$ ), the activity of ${ }^{226} \mathrm{Ra}$ was determined from the $352 \mathrm{keV}$ line of ${ }^{214} \mathrm{~Pb}$ (LLD: $0.5 \mathrm{~Bq} \mathrm{~kg}^{-1}$ ) (Van Cleef, 1994$) ;{ }^{210} \mathrm{~Pb}$ activity was determined from the $47 \mathrm{keV}$ photopeak (LLD: $3.2 \mathrm{~Bq} \mathrm{~kg}^{-1}$ ), ${ }^{40} \mathrm{~K}$ from the $1461 \mathrm{keV}$ photopeak (LLD: $2 \mathrm{~Bq} \mathrm{~kg}^{-1}$ ); ${ }^{232} \mathrm{Th}$ was estimated using the $911 \mathrm{keV}$ photopeak of ${ }^{228} \mathrm{Ac}$ (LLD: $0.5 \mathrm{~Bq} \mathrm{~kg}^{-1}$ ), and ${ }^{137} \mathrm{Cs}$ activity was determined from the $661.6 \mathrm{keV}$ photopeak (LLD: $0.2 \mathrm{~Bq} \mathrm{~kg}^{-1}$ ). The ${ }^{210} \mathrm{~Pb}$ (halflife $=22.26 \mathrm{yr}$ ) is integrated by the "in situ"-produced fraction from the decay of ${ }^{226} \mathrm{Ra}$ (Appleby and Oldfield, 1992) and the upward diffusion of ${ }^{222} \mathrm{Rn}$ in the atmosphere, which is the source of ${ }^{210} \mathrm{~Pb}_{\mathrm{ex}}$. Spectrometric measurements were performed a month after the samples were sealed, which ensured a secular equilibrium between ${ }^{222} \mathrm{Rn}$ and ${ }^{226} \mathrm{Ra}$. The ${ }^{210} \mathrm{~Pb}_{\text {ex }}$ activities were estimated from the difference between the total ${ }^{210} \mathrm{~Pb}$ activity and the ${ }^{226} \mathrm{Ra}$ activity.

A one-way analysis of variance (ANOVA) was applied to analyse the statistical significance of the differences in the means of the study parameters $(p<0.05)$ using the least significant difference (LSD Fisher) test. The normality of data was tested using the Wilk-Shapiro test $(p<0.05)$. Pearson's linear correlations were also established to assess the relationships between the study elements and between the radionuclides and soil properties and significance was set at $p<0.05$.

\section{Results}

\subsection{Characteristics of the soil profiles}

The soil profiles in the Bødalen and Erdalen drainage basins were acidic, with a $\mathrm{pH}$ ranging from 4.45 to 5.85 , and the predominant soil textures were sandy loam. The percentages of rock fragments and stones $(>2 \mathrm{~mm}$ ) were much higher in the moraine than in the colluvium profiles. Contents in SOC were low on average (2.03\%, SD: 3.16), range between 0.03 to $14.39 \%$ and had large variability (CV : 156 $\%)$. The contents of ACF were always higher than the SCF, especially in the colluvium profiles. There were differences between the properties of the soil profiles on the moraines and on colluviums (Table 2). The latter were significantly less stony and more acidic. Comparing with the Leptosols on the moraines that did not present horizon differentiation, the soils on the colluvium were deeper and better developed with a rich organic A horizon, and relatively higher SOC and 
Table 2. Summary statistics of main properties in the soil samples on moraines and colluvium. Different letters indicate significant differences at the $p$ level 0.05 between moraines and colluvium soils.

\begin{tabular}{|c|c|c|c|c|c|c|c|c|c|c|c|c|}
\hline \multirow[b]{3}{*}{ SOC \% } & \multicolumn{6}{|c|}{ Moraines $n=9$} & \multicolumn{6}{|c|}{ Colluvium $n=12$} \\
\hline & \multicolumn{2}{|c|}{ Mean } & \multirow{2}{*}{$\frac{\text { SD }}{0.44}$} & \multirow{2}{*}{$\begin{array}{l}\text { Min } \\
0.03\end{array}$} & \multirow{2}{*}{$\begin{array}{c}\text { Max } \\
1.03\end{array}$} & \multirow{2}{*}{$\frac{\mathrm{CV}}{91}$} & \multicolumn{2}{|c|}{ Mean } & \multirow{2}{*}{$\begin{array}{c}\text { SD } \\
3.82\end{array}$} & \multirow{2}{*}{$\begin{array}{l}\text { Min } \\
0.43\end{array}$} & \multirow{2}{*}{$\begin{array}{c}\text { Max } \\
14.39\end{array}$} & \multirow{2}{*}{$\begin{array}{l}\text { CV } \\
120\end{array}$} \\
\hline & 0.48 & $\mathrm{a}$ & & & & & 3.18 & $\mathrm{a}$ & & & & \\
\hline ACF \% & 0.28 & $\mathrm{a}$ & 0.31 & 0.03 & 0.79 & 137 & 2.78 & $\mathrm{a}$ & 3.40 & 0.38 & 12.69 & 123 \\
\hline SCF \% & 0.07 & $\mathrm{a}$ & 0.05 & 0.01 & 0.12 & 276 & 0.36 & $\mathrm{a}$ & 0.31 & 0.03 & 1.10 & 84 \\
\hline Stones \% & 60.21 & $\mathrm{~b}$ & 20.30 & 28.59 & 87.59 & 34 & 18.00 & $\mathrm{a}$ & 23.55 & 0.13 & 80.59 & 131 \\
\hline $\mathrm{pH}$ & 5.45 & $\mathrm{~b}$ & 0.33 & 5.02 & 5.85 & 5 & 4.80 & $\mathrm{a}$ & 0.24 & 4.45 & 5.16 & 5 \\
\hline $2000-50 \mu \mathrm{m} \%$ & 72.58 & $\mathrm{a}$ & 21.84 & 42.40 & 95.00 & 30 & 60.28 & $\mathrm{a}$ & 23.52 & 13.50 & 81.60 & 39 \\
\hline $50-2 \mu \mathrm{m} \%$ & 23.86 & $\mathrm{a}$ & 18.51 & 4.60 & 49.20 & 78 & 36.22 & $\mathrm{a}$ & 20.36 & 17.40 & 75.70 & 56 \\
\hline$<2 \mu \mathrm{m} \%$ & 3.52 & $\mathrm{a}$ & 3.36 & 0.40 & 8.40 & 96 & 3.51 & $\mathrm{a}$ & 3.21 & 1.00 & 10.80 & 92 \\
\hline
\end{tabular}

SD: Standard deviation, CV: Coefficient of variation $\%$.

carbon fractions. Soil samples of the moraines had higher sand contents and lower silt contents than samples of the colluvium, but clay contents were similar and low.

The most abundant elements in the studied profiles were $\mathrm{Al}, \mathrm{Fe}, \mathrm{Na}$, and $\mathrm{K}(\bar{x}: 47071,27608,25205$ and $\left.23723 \mathrm{mg} \mathrm{kg}^{-1}\right), \mathrm{Ca}$ and $\mathrm{Mg}$ were also major components $\left(\bar{x}: 10492,7497 \mathrm{mg} \mathrm{kg}^{-1}\right)$, followed by Ti, B and $\mathrm{P}(\bar{x}: 3942$, 1948 and $\left.1068 \mathrm{mg} \mathrm{kg}^{-1}\right), \mathrm{Mn}, \mathrm{Sr}$ and $\mathrm{S}(\bar{x}: 448,279$ and $\left.266 \mathrm{~m} \mathrm{~kg}^{-1}\right)$, and $\mathrm{Cr}, \mathrm{V}, \mathrm{Zn}, \mathrm{Ni}, \mathrm{Tl}, \mathrm{Pb}$ and $\mathrm{Bi}(\bar{x}: 90,54$, 47, 43, 39, 28 and $23 \mathrm{mg} \mathrm{kg}^{-1}$ ) whereas $\mathrm{Li}, \mathrm{Sb}, \mathrm{Be}$ and $\mathrm{Mo}$ had the lower contents $\left(\bar{x}: 8.4,2.4,1.3\right.$ and $\left.0.7 \mathrm{mg} \mathrm{kg}^{-1}\right)$; As and $\mathrm{Cd}$ were not detected in the study samples (Table 3).

The mean contents of $\mathrm{Al}$ were similar in colluvium and moraine profiles, although the variation range was higher in the colluvium profiles (Table 3). Of the major elements, mean $\mathrm{Fe}, \mathrm{Ca}$ and $\mathrm{Mg}$ contents were significantly lower in the moraine profiles, whereas the opposite was observed for $\mathrm{Na}$ and $\mathrm{K}$. In lower concentration ranges (91-6500 $\mathrm{m} \mathrm{kg}^{-1}$ ), the mean contents of $\mathrm{Sr}, \mathrm{S}, \mathrm{Mn}, \mathrm{P}$ and Ti were significantly lower in samples of the moraines than in the colluvium ones, but the opposite was found for B which was much higher in the moraine samples. In minor concentrations (ranges between 5 and $330 \mathrm{mg} \mathrm{kg}^{-1}$ ), the contents of $\mathrm{Tl}, \mathrm{V}, \mathrm{Zn}, \mathrm{Ni}$ and $\mathrm{Cr}$ were significantly lower in moraine samples than in colluvium soils. On the other hand, significantly higher contents of $\mathrm{Pb}$ and $\mathrm{Be}$ were found in colluvium soils. Other trace elements like Mo and Sb had significantly lower contents in moraine samples, and likewise for $\mathrm{Li}, \mathrm{Bi}$ and $\mathrm{Cu}$, although for the latter differences were not significant. For all samples most elements were directly correlated among them. However, $\mathrm{Na}, \mathrm{K}, \mathrm{Pb}$, and $\mathrm{Be}$ were mostly inversely correlated with the rest of the elements and directly correlated between them (Table 4). When considering the moraines and colluviums separately, the Pearson's coefficients of correlation of the moraine profiles showed similar patterns (Table 5), although correlations had lower significances. For the colluvium profiles (whilst $\mathrm{Pb}$ and $\mathrm{Na}$ maintained inverse relationships with the rest of the elements) Be and $\mathrm{K}$ showed different trends and few correlations were significant (Table 6).

The radioisotope mass activities ranges $\left(\mathrm{Bq} \mathrm{kg}^{-1}\right)$ were 28.1-64.9 for ${ }^{238} \mathrm{U}, 12.6-47.7$ for ${ }^{226} \mathrm{Ra}, 12.6-83.7$ for ${ }^{232} \mathrm{Th}, 652-1320$ for ${ }^{40} \mathrm{~K}$, b.d.l.(below detection limit)-118 for ${ }^{210} \mathrm{~Pb}$, b.d.1. -102.4 for ${ }^{210} \mathrm{~Pb}_{\mathrm{ex}}$, and $1.2-346$ for ${ }^{137} \mathrm{Cs}$ (Table 7). The mean contents of FRNs were much lower in the soils of the moraines, although differences were not significant. The range of variation of ${ }^{137} \mathrm{Cs}$ and ${ }^{210} \mathrm{~Pb}_{\mathrm{ex}}$ in the samples of the colluviums was much larger than that of the moraines. Apart from ${ }^{210} \mathrm{~Pb}$, the ERN contents were significantly higher in the moraine samples.

The correlations established among the FRNs with the soil properties showed that in the moraine profiles ${ }^{137} \mathrm{Cs}$ was related directly and significantly with SOC, ACF and sand contents, but inversely with the $\mathrm{pH}$ and the silt and clay fractions (Table 8). However, in the colluvium profiles ${ }^{137} \mathrm{Cs}$ was only significantly correlated with SCF content and the correlations with the fine fractions were direct but not significant. Concerning the ${ }^{210} \mathrm{~Pb}_{\mathrm{ex}}$ the only significant correlation was that with the SCF content in the colluvium profiles.

Few correlations of ERNs with soil properties were significant in the colluvium profiles (Table 8). The type of correlations were similar for ${ }^{232} \mathrm{Th}$ and ${ }^{40} \mathrm{~K}$, as both radionuclides were directly related with the fine fractions but inversely related with the soil organic carbon and the sand contents; whereas the opposite was true for ${ }^{226} \mathrm{Ra}$ and ${ }^{238} \mathrm{U}$. However, in the moraine profiles the type of correlations was different and not significant.

\subsection{Distribution of soil properties and elements in the profiles}

The vertical distribution of main soil properties, radionuclide and element contents in the study soils showed very distinctive patterns in the moraine and the colluvium profiles. The SOC distribution down the profiles of moraine soils was quite homogeneous and contents were much lower than in the 
Table 3. Summary statistics of the elemental composition $\left(\mathrm{mg} \mathrm{kg}^{-1}\right)$ in the samples of the soil profiles of the moraines and colluviums. Different letters indicate significant differences at the $p$ level 0.05 between moraines and colluvium soils.

\begin{tabular}{|c|c|c|c|c|c|c|c|c|c|c|c|c|}
\hline & \multicolumn{6}{|c|}{ Moraines $n=9$} & \multicolumn{6}{|c|}{ Colluvium $n=12$} \\
\hline & Mean & & SD & Min & Max & $\mathrm{CV}$ & Mean & & SD & Min & Max & $\mathrm{CV}$ \\
\hline $\mathrm{Be}$ & 1.5 & $\mathrm{~b}$ & 0.0 & 1.4 & 1.5 & 2 & 1.1 & a & 0.1 & 0.8 & 1.3 & 12 \\
\hline Mo & 0.5 & $\mathrm{a}$ & 0.2 & b.d.1. & 0.7 & 41 & 0.8 & $\mathrm{~b}$ & 0.1 & 0.6 & 1.0 & 17 \\
\hline $\mathrm{Sb}$ & 1.4 & a & 0.3 & 0.9 & 1.8 & 18 & 3.1 & $\mathrm{~b}$ & 1.1 & 1.6 & 5.1 & 35 \\
\hline $\mathrm{Li}$ & 7.6 & a & 1.0 & 5.2 & 8.5 & 13 & 9.0 & a & 6.0 & 0.8 & 17.4 & 67 \\
\hline $\mathrm{Bi}$ & 21.6 & $\mathrm{a}$ & 1.6 & 18.6 & 23.8 & 8 & 24.4 & $\mathrm{a}$ & 7.2 & 12.1 & 34.2 & 30 \\
\hline $\mathrm{Cu}$ & 17.3 & $\mathrm{a}$ & 10.5 & 7.1 & 41.2 & 61 & 22.7 & $\mathrm{a}$ & 13.2 & 5.6 & 47.3 & 58 \\
\hline $\mathrm{Pb}$ & 31.0 & $\mathrm{~b}$ & 1.0 & 29.5 & 32.6 & 3 & 26.6 & $\mathrm{a}$ & 3.6 & 19.3 & 31.8 & 14 \\
\hline $\mathrm{Tl}$ & 24.6 & $\mathrm{a}$ & 3.4 & 19.2 & 29.7 & 14 & 49.6 & b & 26.0 & 13.0 & 86.4 & 53 \\
\hline V & 34.9 & $\mathrm{a}$ & 4.9 & 25.9 & 40.3 & 14 & 69.1 & $\mathrm{~b}$ & 21.3 & 32.8 & 99.3 & 31 \\
\hline $\mathrm{Zn}$ & 29.8 & $\mathrm{a}$ & 2.5 & 23.9 & 33.1 & 8 & 58.9 & b & 34.8 & 9.6 & 110.0 & 59 \\
\hline $\mathrm{Ni}$ & 27.0 & $\mathrm{a}$ & 2.9 & 22.4 & 31.4 & 11 & 55.6 & b & 37.7 & 14.0 & 121.0 & 68 \\
\hline $\mathrm{Cr}$ & 25.1 & $\mathrm{a}$ & 4.6 & 17.1 & 30.5 & 19 & 139.0 & $\mathrm{~b}$ & 99.0 & 30.6 & 323.9 & 71 \\
\hline $\mathrm{Sr}$ & 241.9 & $\mathrm{a}$ & 16.3 & 212.7 & 261.1 & 30 & 306.2 & a & 94.3 & 172.1 & 465.5 & 31 \\
\hline S & 125.1 & $\mathrm{a}$ & 37.2 & 90.8 & 216.2 & 30 & 371.3 & b & 232.9 & 191.5 & 1005.0 & 63 \\
\hline $\mathrm{Mn}$ & 275.3 & $\mathrm{a}$ & 40.2 & 211.7 & 336.7 & 15 & 571.7 & b & 349.3 & 117.5 & 1088.0 & 61 \\
\hline $\mathrm{P}$ & 839.3 & $\mathrm{a}$ & 109.3 & 613.6 & 942.8 & 13 & 1239.9 & b & 356.0 & 545.4 & 1791.0 & 29 \\
\hline B & 3197.8 & $\mathrm{~b}$ & 237.5 & 2970.0 & 3770.0 & 7 & 1010.1 & $\mathrm{a}$ & 796.4 & 300.7 & 3090.0 & 79 \\
\hline $\mathrm{Ti}$ & 3092.2 & $\mathrm{a}$ & 419.0 & 2240.0 & 3840.0 & 14 & 4580.0 & b & 1070.0 & 2720.0 & 6500.0 & 23 \\
\hline $\mathrm{Mg}$ & 2710.8 & $\mathrm{a}$ & 610.1 & 1771.0 & 3633.0 & 23 & 11086.1 & b & 8748.6 & 1206.0 & 25100.0 & 79 \\
\hline $\mathrm{Ca}$ & 8241.4 & $\mathrm{a}$ & 778.3 & 6516.0 & 8982.0 & 9 & 12180.0 & b & 2496.8 & 6728.0 & 16140.0 & 21 \\
\hline K & 28358.9 & b & 1423.5 & 26140.0 & 30120.0 & 5 & 20246.7 & $\mathrm{a}$ & 3394.7 & 12810.0 & 24980.0 & 17 \\
\hline $\mathrm{Na}$ & 30607.8 & b & 1579.4 & 29000.0 & 33940.0 & 5 & 21153.3 & $\mathrm{a}$ & 4763.4 & 13520.0 & 27270.0 & 23 \\
\hline $\mathrm{Fe}$ & 19300.0 & $\mathrm{a}$ & 2500.9 & 15490.0 & 22960.0 & 13 & 33838.4 & $\mathrm{~b}$ & 15949.9 & 9471.0 & 56000.0 & 47 \\
\hline $\mathrm{Al}$ & 45526.7 & $\mathrm{a}$ & 4215.0 & 40330.0 & 53590.0 & 9 & 48230.0 & $\mathrm{a}$ & 10710.9 & 27050.0 & 61550.0 & 22 \\
\hline
\end{tabular}

SD: Standard deviation, CV: Coefficient of variation \%, b.d.l.: below detection limit

Table 4. Pearson correlation coefficients among elements $\left(\mathrm{mg} \mathrm{kg}^{-1}\right)$ in the samples of all soil profiles. Bold face numbers are significant at the $95 \%$ confidence level, underlined numbers are significant at the $99 \%$ confidence level.

\begin{tabular}{|c|c|c|c|c|c|c|c|c|c|c|c|c|c|c|c|c|c|c|c|c|c|c|c|}
\hline & Mo & $\mathrm{Sb}$ & $\mathrm{Li}$ & $\mathrm{Bi}$ & $\mathrm{Cu}$ & $\mathrm{Pb}$ & $\mathrm{Tl}$ & V & $\mathrm{Zn}$ & $\mathrm{Ni}$ & $\mathrm{Cr}$ & $\mathrm{Sr}$ & $\mathrm{S}$ & $\mathrm{Mn}$ & $\mathrm{Pb}$ & B & $\mathrm{Ti}$ & $\mathrm{Ca}$ & $\mathrm{Mg}$ & $\mathrm{K}$ & $\mathrm{Al}$ & $\mathrm{Na}$ & $\mathrm{Fe}$ \\
\hline $\mathrm{Be}$ & -0.682 & -0.535 & 0.050 & -0.014 & -0.150 & $\underline{0.661}$ & -0.360 & -0.522 & -0.310 & -0.363 & -0.508 & -0.052 & $\underline{-0.817}$ & -0.353 & -0.341 & $\underline{0.765}$ & -0.431 & -0.337 & -0.417 & $\underline{0.914}$ & 0.138 & $\underline{0.809}$ & -0.351 \\
\hline Mo & & $\underline{0.573}$ & 0.156 & 0.296 & 0.088 & $-\overline{0.371}$ & 0.466 & 0.537 & 0.451 & 0.426 & 0.524 & 0.189 & $\overline{0.548}$ & 0.494 & 0.406 & $-\overline{0.502}$ & 0.389 & 0.433 & 0.470 & $-\overline{0.565}$ & 0.062 & $\underline{-0.755}$ & 0.458 \\
\hline $\mathrm{Sb}$ & & & $\underline{0.702}$ & $\underline{0.743}$ & 0.499 & -0.481 & $\underline{0.934}$ & $\underline{0.935}$ & $\underline{0.886}$ & $\underline{0.876}$ & $\underline{0.952}$ & 0.454 & 0.257 & $\underline{0.885}$ & 0.537 & -0.659 & $\underline{0.766}$ & $\underline{0.772}$ & $\underline{0.944}$ & $\overline{-0.453}$ & $\underline{0.635}$ & -0.815 & $\underline{0.895}$ \\
\hline $\mathrm{Li}$ & & & & $\underline{0.953}$ & $\underline{0.685}$ & -0.097 & $\underline{0.877}$ & $\underline{\underline{0.720}}$ & $\overline{0.902}$ & $\overline{0.746}$ & $\overline{0.726}$ & 0.537 & -0.134 & $\underline{0.847}$ & 0.430 & -0.105 & $\overline{0.551}$ & $\overline{0.490}$ & $\overline{0.826}$ & 0.175 & $\overline{0.895}$ & -0.463 & $\underline{0.893}$ \\
\hline $\mathrm{Bi}$ & & & & & $\underline{0.659}$ & -0.045 & $\overline{0.903}$ & $\overline{0.794}$ & $\overline{0.926}$ & $\underline{\underline{0.759}}$ & $\overline{0.745}$ & $\underline{0.627}$ & -0.119 & $\underline{0.887}$ & 0.519 & -0.124 & $\underline{0.636}$ & $\underline{0.638}$ & $\underline{\underline{0.830}}$ & 0.110 & $\overline{0.916}$ & -0.503 & $\underline{0.913}$ \\
\hline $\mathrm{Cu}$ & & & & & & -0.386 & $\underline{\underline{0.658}}$ & $\overline{0.548}$ & $\overline{0.689}$ & $\overline{0.663}$ & $\underline{\underline{0.616}}$ & $\overline{0.233}$ & 0.096 & $\overline{0.685}$ & 0.248 & -0.161 & 0.393 & 0.316 & $\underline{0.631}$ & -0.109 & 0.469 & -0.465 & $\underline{0.689}$ \\
\hline $\mathrm{Pb}$ & & & & & & & $-\overline{0.357}$ & -0.357 & $-\overline{0.286}$ & $-\overline{0.418}$ & $-\overline{0.500}$ & 0.054 & $\underline{-0.550}$ & $-\overline{0.331}$ & -0.317 & $\underline{0.681}$ & -0.187 & -0.310 & $-\overline{0.413}$ & $\underline{0.692}$ & 0.058 & $\underline{0.642}$ & $-\overline{0.376}$ \\
\hline $\mathrm{Tl}$ & & & & & & & & $\underline{0.911}$ & $\underline{0.986}$ & $\underline{0.919}$ & $\underline{0.946}$ & $\underline{0.493}$ & 0.149 & $\underline{0.975}$ & 0.529 & -0.431 & $\underline{0.688}$ & $\underline{0.699}$ & $\underline{0.980}$ & $-\overline{0.263}$ & $\underline{0.794}$ & $\underline{-0.744}$ & $\underline{0.973}$ \\
\hline $\mathrm{V}$ & & & & & & & & & $\underline{0.895}$ & $\underline{0.774}$ & $\underline{0.864}$ & $\underline{0.633}$ & 0.226 & $\underline{0.892}$ & $\underline{0.612}$ & -0.658 & $\underline{0.909}$ & 0.796 & $\underline{0.892}$ & -0.377 & $\underline{0.676}$ & -0.816 & $\underline{0.910}$ \\
\hline $\mathrm{Zn}$ & & & & & & & & & & $\underline{0.869}$ & $\overline{0.896}$ & $\overline{0.541}$ & 0.155 & $\underline{0.978}$ & $\underline{0.552}$ & -0.384 & $\underline{0.685}$ & 0.657 & $\underline{0.953}$ & -0.202 & $\overline{0.796}$ & $\underline{-0.735}$ & $\underline{0.980}$ \\
\hline $\mathrm{Ni}$ & & & & & & & & & & & $\overline{0.974}$ & 0.145 & 0.087 & $\overline{0.908}$ & $\overline{0.223}$ & -0.341 & $\overline{0.489}$ & $\overline{\mathbf{0 . 5 4 0}}$ & $\overline{0.949}$ & -0.305 & $\overline{\underline{0.643}}$ & $\overline{-0.641}$ & $\overline{0.834}$ \\
\hline $\mathrm{Cr}$ & & & & & & & & & & & & 0.253 & 0.233 & $\underline{0.921}$ & 0.366 & -0.519 & $\underline{0.611}$ & $\underline{0.626}$ & $\underline{0.976}$ & -0.430 & $\underline{\underline{0.620}}$ & -0.774 & $\underline{0.882}$ \\
\hline $\mathrm{Sr}$ & & & & & & & & & & & & & 0.006 & $\overline{0.428}$ & $\underline{0.834}$ & -0.352 & $\underline{0.733}$ & $\underline{0.754}$ & 0.357 & 0.029 & $\underline{0.641}$ & -0.379 & $\underline{0.582}$ \\
\hline S & & & & & & & & & & & & & & 0.137 & $\overline{0.423}$ & -0.545 & $\overline{0.162}$ & $\overline{0.071}$ & 0.188 & -0.796 & $-\overline{0.310}$ & -0.688 & 0.219 \\
\hline $\mathrm{Mn}$ & & & & & & & & & & & & & & & 0.458 & -0.398 & $\underline{0.662}$ & $\underline{0.621}$ & $\underline{0.963}$ & -0.239 & $\underline{0.738}$ & -0.742 & $\underline{0.953}$ \\
\hline $\mathrm{Pb}$ & & & & & & & & & & & & & & & & -0.530 & $\overline{0.604}$ & $\overline{\underline{0.755}}$ & $\overline{0.420}$ & -0.331 & $\overline{0.464}$ & $\overline{-0.614}$ & $\underline{0.630}$ \\
\hline B & & & & & & & & & & & & & & & & & $=\overline{-0.677}$ & $-\overline{-0.580}$ & -0.476 & $\underline{0.728}$ & -0.024 & $\overline{\mathbf{0 . 7 7 2}}$ & $-\overline{\mathbf{0 . 4 4 9}}$ \\
\hline $\mathrm{Ti}$ & & & & & & & & & & & & & & & & & & $\overline{0.749}$ & $\underline{0.662}$ & $-\overline{0.278}$ & 0.536 & $\overline{-0.668}$ & $\underline{0.728}$ \\
\hline $\mathrm{Ca}$ & & & & & & & & & & & & & & & & & & & $\underline{0.615}$ & -0.355 & $\underline{0.624}$ & $\overline{-0.556}$ & $\underline{0.681}$ \\
\hline $\mathrm{Mg}$ & & & & & & & & & & & & & & & & & & & & -0.315 & $\underline{\underline{0.708}}$ & $\overline{-0.766}$ & $\underline{0.944}$ \\
\hline $\mathrm{K}$ & & & & & & & & & & & & & & & & & & & & & $\overline{0.246}$ & $\underline{0.665}$ & $-\overline{0.227}$ \\
\hline $\mathrm{Al}$ & & & & & & & & & & & & & & & & & & & & & & $-\overline{0.289}$ & $\underline{0.782}$ \\
\hline $\mathrm{Na}$ & & & & & & & & & & & & & & & & & & & & & & & -0.782 \\
\hline
\end{tabular}

colluvium profiles (Fig. 4). The PB1 profile had the lowest SOC (below $0.1 \%$ ), most in the active form with almost negligible amounts of the stable carbon fraction, which was also very low in PB2. The vertical distribution of SOC contents in the colluvium profiles showed decreasing trends with depth, which were more marked in PB3. The PE2 profile showed a large SOC enrichment at the 10-14 cm interval depth, most of it in active form (ACF reaches $12.7 \%$ ). The $\mathrm{pH}$ profiles showed little variations with depth, both in the moraine and the colluvium profiles, and values were slightly lower at the topsoil than at deeper layers. 
Table 5. Pearson correlation coefficients among elements $\left(\mathrm{mg} \mathrm{kg}^{-1}\right)$ in the samples of the moraine profiles. Bold face numbers are significant at the $95 \%$ confidence level, underlined numbers are significant at the $99 \%$ confidence level.

\begin{tabular}{|c|c|c|c|c|c|c|c|c|c|c|c|c|c|c|c|c|c|c|c|c|c|c|c|}
\hline & Mo & $\mathrm{Sb}$ & $\mathrm{Li}$ & $\mathrm{Bi}$ & $\mathrm{Cu}$ & $\mathrm{Pb}$ & $\mathrm{Tl}$ & $\mathrm{V}$ & $\mathrm{Zn}$ & $\mathrm{Ni}$ & $\mathrm{Cr}$ & $\mathrm{Sr}$ & $S$ & $\mathrm{Mn}$ & $\mathrm{P}$ & B & $\mathrm{Ti}$ & $\mathrm{Ca}$ & $\mathrm{Mg}$ & $\mathrm{K}$ & $\mathrm{Al}$ & $\mathrm{Na}$ & $\mathrm{Fe}$ \\
\hline $\mathrm{Be}$ & -0.613 & -0.632 & -0.460 & -0.747 & 0.401 & -0.146 & -0.784 & -0.697 & -0.479 & -0.178 & -0.786 & -0.823 & -0.062 & -0.696 & -0.693 & -0.311 & -0.408 & -0.641 & -0.745 & -0.062 & -0.301 & 0.628 & -0.679 \\
\hline Mo & & $\underline{0.890}$ & -0.210 & 0.293 & -0.728 & 0.521 & 0.106 & 0.369 & -0.141 & -0.615 & 0.329 & $\overline{0.474}$ & 0.108 & 0.057 & 0.314 & -0.221 & 0.186 & 0.487 & 0.077 & 0.452 & -0.090 & -0.915 & 0.135 \\
\hline $\mathrm{Sb}$ & & & -0.135 & 0.483 & -0.447 & 0.317 & 0.135 & 0.541 & -0.136 & -0.378 & 0.457 & 0.502 & 0.351 & 0.132 & 0.420 & -0.139 & 0.546 & 0.651 & 0.045 & 0.260 & -0.143 & -0.822 & 0.374 \\
\hline $\mathrm{Li}$ & & & & 0.464 & 0.211 & -0.513 & $\underline{0.802}$ & 0.280 & $\underline{0.947}$ & 0.555 & 0.491 & 0.265 & 0.060 & $\underline{0.798}$ & 0.249 & 0.496 & 0.058 & -0.104 & 0.784 & -0.361 & 0.468 & $\overline{0.230}$ & 0.603 \\
\hline $\mathrm{Bi}$ & & & & & -0.074 & 0.176 & $\overline{\mathbf{0 . 7 8 7}}$ & $\underline{0.970}$ & $\overline{0.445}$ & 0.422 & $\underline{0.971}$ & $\underline{0.829}$ & 0.098 & $\overline{0.844}$ & $\underline{0.891}$ & 0.639 & 0.769 & 0.721 & 0.671 & 0.094 & 0.515 & -0.235 & $\underline{0.952}$ \\
\hline $\mathrm{Cu}$ & & & & & & -0.763 & -0.132 & -0.138 & 0.176 & 0.611 & -0.185 & -0.425 & 0.580 & -0.108 & $-\overline{0.298}$ & 0.035 & 0.288 & -0.262 & -0.235 & -0.711 & -0.330 & 0.578 & 0.152 \\
\hline $\mathrm{Pb}$ & & & & & & & -0.027 & 0.296 & -0.398 & -0.459 & 0.199 & 0.414 & -0.577 & 0.007 & 0.377 & 0.218 & -0.016 & 0.387 & 0.014 & 0.786 & 0.395 & -0.323 & -0.055 \\
\hline $\mathrm{Tl}$ & & & & & & & & 0.653 & 0.797 & 0.560 & 0.809 & 0.767 & -0.170 & 0.956 & 0.684 & 0.662 & 0.282 & 0.409 & $\underline{0.978}$ & -0.118 & 0.687 & -0.070 & 0.776 \\
\hline $\mathrm{V}$ & & & & & & & & & 0.260 & 0.280 & $\underline{0.962}$ & $\underline{0.805}$ & 0.113 & $\overline{0.738}$ & $\underline{0.928}$ & 0.547 & $\underline{0.810}$ & 0.764 & $\overline{0.533}$ & 0.256 & 0.412 & -0.336 & $\underline{0.891}$ \\
\hline $\mathrm{Zn}$ & & & & & & & & & & 0.502 & 0.450 & 0.256 & 0.067 & 0.757 & 0.170 & 0.572 & -0.002 & -0.155 & 0.769 & -0.324 & 0.479 & 0.208 & 0.597 \\
\hline $\mathrm{Ni}$ & & & & & & & & & & & 0.340 & 0.286 & 0.033 & 0.514 & 0.300 & 0.548 & 0.358 & 0.212 & 0.518 & -0.631 & 0.343 & 0.505 & 0.526 \\
\hline $\mathrm{Cr}$ & & & & & & & & & & & & $\underline{0.831}$ & 0.023 & 0.877 & $\underline{0.934}$ & 0.592 & 0.674 & 0.673 & 0.720 & 0.216 & 0.516 & -0.305 & $\underline{0.908}$ \\
\hline $\mathrm{Sr}$ & & & & & & & & & & & & & -0.221 & 0.710 & $\underline{0.881}$ & 0.422 & 0.499 & $\underline{0.860}$ & 0.731 & 0.123 & 0.540 & -0.455 & 0.651 \\
\hline S & & & & & & & & & & & & & & -0.172 & $-\overline{0.173}$ & -0.340 & 0.511 & 0.023 & -0.336 & -0.438 & -0.699 & -0.253 & 0.262 \\
\hline $\mathrm{Mn}$ & & & & & & & & & & & & & & & 0.750 & 0.742 & 0.366 & 0.373 & $\underline{0.919}$ & 0.036 & 0.742 & 0.018 & $\underline{0.843}$ \\
\hline $\mathrm{P}$ & & & & & & & & & & & & & & & & 0.503 & 0.649 & $\underline{0.802}$ & $\overline{0.630}$ & 0.318 & 0.518 & -0.326 & $\overline{0.746}$ \\
\hline B & & & & & & & & & & & & & & & & & 0.271 & 0.164 & 0.633 & 0.150 & 0.828 & 0.424 & 0.686 \\
\hline $\mathrm{Ti}$ & & & & & & & & & & & & & & & & & & 0.731 & 0.107 & -0.082 & $-\overline{-0.021}$ & -0.233 & 0.762 \\
\hline $\mathrm{Ca}$ & & & & & & & & & & & & & & & & & & & 0.333 & 0.069 & 0.185 & -0.533 & 0.532 \\
\hline $\mathrm{Mg}$ & & & & & & & & & & & & & & & & & & & & -0.070 & 0.735 & -0.040 & 0.641 \\
\hline $\mathrm{K}$ & & & & & & & & & & & & & & & & & & & & & 0.257 & -0.289 & -0.048 \\
\hline $\mathrm{Al}$ & & & & & & & & & & & & & & & & & & & & & & 0.330 & 0.439 \\
\hline $\mathrm{Na}$ & & & & & & & & & & & & & & & & & & & & & & & -0.086 \\
\hline
\end{tabular}

Table 6. Pearson correlation coefficients among elements $\left(\mathrm{mg} \mathrm{kg}^{-1}\right)$ in the samples of colluvium profiles. Bold face numbers are significant at the $95 \%$ confidence level, underlined numbers are significant at the $99 \%$ confidence level.

\begin{tabular}{|c|c|c|c|c|c|c|c|c|c|c|c|c|c|c|c|c|c|c|c|c|c|c|c|}
\hline & Mo & $\mathrm{Sb}$ & $\mathrm{Li}$ & $\mathrm{Bi}$ & $\mathrm{Cu}$ & $\mathrm{Pb}$ & $\mathrm{Tl}$ & V & $\mathrm{Zn}$ & $\mathrm{Ni}$ & $\mathrm{Cr}$ & $\mathrm{Sr}$ & $\mathrm{S}$ & $\mathrm{Mn}$ & $\mathrm{P}$ & B & Ti & $\mathrm{Ca}$ & $\mathrm{Mg}$ & $\mathrm{K}$ & $\mathrm{Al}$ & $\mathrm{Na}$ & $\mathrm{Fe}$ \\
\hline $\mathrm{Be}$ & -0.486 & 0.267 & 0.383 & 0.448 & 0.053 & 0.336 & 0.270 & 0.338 & 0.265 & 0.071 & 0.058 & 0.695 & -0.777 & 0.185 & 0.465 & 0.077 & 0.423 & 0.857 & 0.129 & 0.759 & 0.601 & 0.401 & 0.247 \\
\hline Mo & & 0.157 & 0.168 & 0.238 & 0.532 & -0.126 & 0.315 & 0.172 & 0.369 & 0.398 & 0.371 & -0.262 & 0.482 & 0.452 & -0.011 & 0.258 & -0.160 & -0.216 & 0.334 & -0.416 & -0.046 & -0.618 & 0.313 \\
\hline $\mathrm{Sb}$ & & & 0.891 & 0.851 & 0.675 & -0.073 & $\underline{0.953}$ & $\underline{0.875}$ & 0.899 & 0.910 & 0.946 & 0.234 & -0.308 & $\underline{0.894}$ & 0.179 & -0.075 & 0.555 & 0.518 & $\underline{0.969}$ & 0.421 & 0.827 & -0.562 & $\underline{0.892}$ \\
\hline $\mathrm{Li}$ & & & & 0.971 & 0.802 & 0.018 & $\underline{0.959}$ & $\underline{0.919}$ & 0.964 & 0.772 & 0.816 & 0.531 & -0.288 & $\underline{0.901}$ & 0.434 & 0.053 & 0.644 & 0.580 & 0.899 & 0.628 & 0.928 & -0.600 & 0.971 \\
\hline $\mathrm{Bi}$ & & & & & 0.795 & 0.149 & 0.950 & 0.922 & 0.967 & 0.759 & 0.781 & 0.586 & -0.351 & 0.913 & 0.454 & 0.190 & 0.647 & 0.678 & 0.863 & 0.655 & 0.951 & -0.529 & 0.949 \\
\hline $\mathrm{Cu}$ & & & & & & -0.278 & $\overline{\underline{0.806}}$ & $\overline{0.729}$ & $\overline{0.817}$ & $\overline{\mathbf{0 . 7 5 4}}$ & $\overline{\mathbf{0 . 7 5 6}}$ & 0.234 & -0.108 & $\overline{\mathbf{0 . 8 3 0}}$ & 0.233 & 0.090 & 0.362 & 0.331 & $\overline{0.762}$ & 0.365 & $\overline{0.647}$ & -0.716 & $\overline{0.824}$ \\
\hline $\mathrm{Pb}$ & & & & & & & $\overline{-0.024}$ & $\overline{0.184}$ & $\overline{0.042}$ & $\overline{-0.187}$ & $-\overline{0.193}$ & 0.447 & -0.287 & $-\overline{-0.030}$ & 0.071 & 0.365 & 0.433 & 0.251 & $-\overline{0.113}$ & 0.367 & 0.192 & $\overline{0.352}$ & $\overline{-0.073}$ \\
\hline $\mathrm{Tl}$ & & & & & & & & $\underline{0.905}$ & $\underline{0.985}$ & $\underline{0.901}$ & $\underline{0.927}$ & 0.341 & -0.250 & $\underline{0.967}$ & 0.295 & 0.104 & 0.539 & 0.535 & $\underline{0.972}$ & 0.462 & $\underline{0.881}$ & -0.635 & $\underline{0.966}$ \\
\hline $\mathrm{V}$ & & & & & & & & & 0.916 & 0.734 & 0.776 & 0.520 & -0.376 & $\underline{0.898}$ & 0.289 & -0.076 & $\underline{0.836}$ & 0.558 & $\underline{0.873}$ & 0.676 & $\underline{0.865}$ & -0.580 & 0.909 \\
\hline $\mathrm{Zn}$ & & & & & & & & & & 0.833 & 0.865 & 0.426 & -0.193 & $\overline{0.972}$ & 0.378 & 0.117 & $\overline{0.578}$ & 0.518 & $\underline{0.939}$ & 0.489 & $\overline{0.873}$ & -0.677 & 0.980 \\
\hline $\mathrm{Ni}$ & & & & & & & & & & & 0.990 & -0.063 & -0.254 & $\underline{0.885}$ & -0.080 & 0.141 & 0.283 & 0.347 & $\underline{0.940}$ & 0.193 & 0.679 & -0.542 & 0.789 \\
\hline $\mathrm{Cr}$ & & & & & & & & & & & & -0.013 & -0.200 & $\underline{0.900}$ & -0.014 & 0.055 & 0.348 & 0.335 & $\underline{0.970}$ & 0.215 & 0.700 & -0.612 & $\underline{0.836}$ \\
\hline $\mathrm{Sr}$ & & & & & & & & & & & & & -0.324 & $\frac{0.272}{0.0}$ & 0.804 & 0.020 & 0.691 & $\underline{0.717}$ & 0.164 & 0.819 & 0.655 & -0.069 & 0.465 \\
\hline S & & & & & & & & & & & & & & -0.219 & $\overline{0.127}$ & -0.081 & -0.425 & $-\overline{0.649}$ & -0.191 & $\overline{-0.724}$ & -0.504 & -0.468 & -0.134 \\
\hline $\mathrm{Mn}$ & & & & & & & & & & & & & & & 0.219 & 0.081 & 0.528 & 0.442 & $\underline{0.952}$ & $\overline{0.406}$ & $\underline{0.790}$ & -0.685 & $\underline{0.938}$ \\
\hline $\mathrm{P}$ & & & & & & & & & & & & & & & & -0.052 & 0.317 & 0.568 & $\overline{0.134}$ & 0.395 & $\overline{0.461}$ & -0.283 & $\overline{0.458}$ \\
\hline B & & & & & & & & & & & & & & & & & -0.297 & 0.157 & -0.001 & -0.043 & 0.199 & 0.247 & 0.007 \\
\hline $\mathrm{Ti}$ & & & & & & & & & & & & & & & & & & 0.498 & 0.501 & $\underline{0.793}$ & 0.652 & -0.308 & 0.600 \\
\hline $\mathrm{Ca}$ & & & & & & & & & & & & & & & & & & & 0.388 & $\underline{0.722}$ & $\underline{0.794}$ & 0.083 & 0.516 \\
\hline $\mathrm{Mg}$ & & & & & & & & & & & & & & & & & & & & 0.337 & $\underline{0.778}$ & -0.679 & 0.926 \\
\hline $\mathrm{K}$ & & & & & & & & & & & & & & & & & & & & & $\overline{0.763}$ & 0.026 & $\overline{0.497}$ \\
\hline $\mathrm{Al}$ & & & & & & & & & & & & & & & & & & & & & & -0.325 & $\underline{0.864}$ \\
\hline $\mathrm{Na}$ & & & & & & & & & & & & & & & & & & & & & & & -0.736 \\
\hline
\end{tabular}

The abundance of sand fractions was general in the study profiles, but differences in the depth distribution arose; thus, sand contents decreased with depth in PB1 that was paralleled with clay content increases in this moraine profile and characterized by diamicton, which is matrix supported. This pattern was not observed in the other moraine profile (PB2) which had very high contents of sand with homogeneous depth distribution. The colluvium profiles of Erdalen had comparable depth distributions of the grain size fractions, with large predominance of sand fractions. However, the PB3 profile of Bødalen showed a quite distinct distribution, with increasing sand contents down the profile and conversely decreasing clay contents with depth.

The depth distributions of the chemical elements were considerably more homogeneous in the soil profiles of the moraines than those of the colluviums (Fig. 5). The contents of most chemical elements in the moraine profiles almost did not vary with depth. Exceptions were some trace elements, namely $\mathrm{Sb}, \mathrm{Mo}, \mathrm{Cu}$, and $\mathrm{B}$ and major elements $\mathrm{K}, \mathrm{Al}$, and $\mathrm{Fe}$. In the profile $\mathrm{PB} 2 \mathrm{Cu}, \mathrm{V}$ and $\mathrm{Fe}$ varied more than in PB1, where $\mathrm{Al}$ varied the most with depth. In contrast, the profiles of the colluviums exhibited larger variations in the element depth distributions and showed clearly distinctive patterns among profiles. The profile PB3 showed decreasing trends in the contents of most elements, apart from $\mathrm{Na}$ and $\mathrm{B}$. In profile PE2 the contents of most elements decreased sharply at $10-15 \mathrm{~cm}$ depth, but the opposite was seen for $\mathrm{Mo}, \mathrm{Cu}$ and $\mathrm{S}$, whose contents increased. In profile PE1 the largest variations in the element contents appeared at the soil surface where there was high SOC (4\%) in combination with low sand content. Most elements showed lower contents at the top layer and decreases were high for $\mathrm{Sb}, \mathrm{Li}, \mathrm{Bi}, \mathrm{Tl}, \mathrm{V}, \mathrm{Zn}$, $\mathrm{Ni}, \mathrm{Cr}, \mathrm{Mg}, \mathrm{Fe}$, but conversely, increases were recorded for $\mathrm{B}$ and $\mathrm{Pb}$. 
Table 7. Summary statistics of radionuclide contents in the samples of the soil profiles of the moraines and colluviums. Different letters indicate significant differences at the $p$ level 0.05 between moraines and colluvium soils.

\begin{tabular}{|c|c|c|c|c|c|c|c|c|c|c|}
\hline \multirow[t]{2}{*}{$\mathrm{Bq} \mathrm{kg}^{-1}$} & \multicolumn{5}{|c|}{ Moraines $n=9$} & \multicolumn{5}{|c|}{ Colluvium $n=12$} \\
\hline & Mean & & SD & Min & Max & Mean & & SD & Min & Max \\
\hline${ }^{137} \mathrm{Cs}$ & 34.63 & $\mathrm{a}$ & 36.96 & 2.33 & 85.10 & 63.38 & $\mathrm{a}$ & 117.55 & 1.23 & 346.00 \\
\hline${ }^{210} \mathrm{~Pb}_{\mathrm{ex}}$ & 2.63 & $\mathrm{a}$ & 5.26 & b.d.l. & 13.00 & 17.93 & $\mathrm{a}$ & 36.64 & b.d.l. & 102.40 \\
\hline${ }^{40} \mathrm{~K}$ & 1177.78 & $\mathrm{~b}$ & 142.02 & 820.00 & 1320.00 & 890.42 & $\mathrm{a}$ & 124.45 & 652.00 & 1070.00 \\
\hline${ }^{226} \mathrm{Ra}$ & 36.84 & $\mathrm{~b}$ & 6.68 & 24.60 & 47.70 & 18.68 & $\mathrm{a}$ & 6.87 & 12.60 & 30.70 \\
\hline${ }^{232} \mathrm{Th}$ & 56.97 & $\mathrm{~b}$ & 13.91 & 33.70 & 83.70 & 39.27 & $\mathrm{a}$ & 13.86 & 12.60 & 61.20 \\
\hline${ }^{238} \mathrm{U}$ & 52.22 & $\mathrm{~b}$ & 7.65 & 41.50 & 64.90 & 38.99 & $\mathrm{a}$ & 6.46 & 28.10 & 47.10 \\
\hline${ }^{210} \mathrm{~Pb}$ & 25.82 & $\mathrm{a}$ & 12.74 & 3.91 & 45.40 & 29.65 & $\mathrm{a}$ & 43.13 & b.d.l. & 118.00 \\
\hline
\end{tabular}

SD: Standard deviation, b.d.1.: below detection limit.

Table 8. Pearson correlation coefficients among soil properties FRN and ERNs in the samples of the soil profiles of the moraines and colluviums. Bold face numbers are significant at the $95 \%$ confidence level, underlined numbers are significant at the $99 \%$ confidence level.

\begin{tabular}{|c|c|c|c|c|c|c|c|}
\hline $\begin{array}{l}\text { FRNs, ERNs } \\
\mathrm{Bq} \mathrm{kg}^{-1}\end{array}$ & $\begin{array}{r}\text { SOC } \\
\%\end{array}$ & $\begin{array}{r}\mathrm{ACF} \\
\%\end{array}$ & $\begin{array}{r}\mathrm{SCF} \\
\%\end{array}$ & $\mathrm{pH}$ & $\begin{array}{r}2000-50 \\
\mu \mathrm{m} \%\end{array}$ & $\begin{array}{r}50-2 \\
\mu \mathrm{m} \%\end{array}$ & $\begin{array}{r}<2 \\
\mu \mathrm{m} \%\end{array}$ \\
\hline \multicolumn{8}{|c|}{ Moraines $n=9$} \\
\hline${ }^{137} \mathrm{Cs}$ & 0.902 & 0.939 & 0.929 & -0.95 & 0.822 & -0.822 & -0.808 \\
\hline${ }^{210} \mathrm{~Pb}_{\mathrm{ex}}$ & $\overline{0.491}$ & $\overline{0.264}$ & 0.087 & $\overline{-0.32}$ & $\overline{0.348}$ & -0.342 & $\overline{-0.376}$ \\
\hline${ }^{40} \mathrm{~K}$ & -0.185 & 0.216 & 0.275 & -0.06 & 0.005 & -0.017 & 0.056 \\
\hline${ }^{226} \mathrm{Ra}$ & 0.201 & 0.524 & 0.084 & -0.37 & 0.363 & -0.368 & -0.336 \\
\hline${ }^{232} \mathrm{Th}$ & 0.298 & 0.459 & -0.143 & -0.5 & 0.496 & -0.503 & -0.454 \\
\hline${ }^{238} \mathrm{U}$ & 0.101 & 0.033 & -0.259 & -0.17 & 0.24 & -0.246 & -0.203 \\
\hline${ }^{210} \mathrm{~Pb}$ & 0.718 & 0.516 & 0.057 & -0.71 & 0.731 & -0.726 & -0.75 \\
\hline \multicolumn{8}{|c|}{ Colluvium $n=12$} \\
\hline${ }^{137} \mathrm{Cs}$ & 0.178 & 0.211 & $\underline{0.852}$ & -0.39 & -0.228 & 0.218 & 0.282 \\
\hline${ }^{210} \mathrm{~Pb}_{\mathrm{ex}}$ & 0.188 & 0.211 & $\overline{\mathbf{0 . 7 6 5}}$ & -0.46 & -0.383 & 0.371 & 0.451 \\
\hline${ }^{40} \mathrm{~K}$ & -0.648 & -0.671 & -0.275 & 0.175 & -0.485 & 0.486 & 0.469 \\
\hline${ }^{226} \mathrm{Ra}$ & 0.014 & 0.047 & 0.537 & 0.287 & 0.503 & -0.502 & -0.5 \\
\hline${ }^{232} \mathrm{Th}$ & -0.043 & -0.066 & -0.446 & -0.2 & -0.799 & $\underline{0.811}$ & $\underline{0.709}$ \\
\hline${ }^{238} \mathrm{U}$ & 0.319 & 0.334 & 0.118 & 0.463 & 0.358 & -0.346 & -0.426 \\
\hline${ }^{210} \mathrm{~Pb}$ & 0.193 & 0.22 & $\underline{0.809}$ & -0.34 & -0.303 & 0.293 & 0.361 \\
\hline
\end{tabular}

\subsection{The vertical distribution of radionuclides}

The mass activities of ${ }^{137} \mathrm{Cs}$ and ${ }^{210} \mathrm{~Pb}_{\mathrm{ex}}$ down the profiles showed different patterns in the moraine and the colluvium profiles (Fig. 6). The moraine profiles did not show exponential decreases of ${ }^{137} \mathrm{Cs}$ with depth and lower contents of ${ }^{137} \mathrm{Cs}$ were found in PB1 (range: $2.3-30.2 \mathrm{~Bq} \mathrm{~kg}^{-1}$ ) than in PB2 $\left(20-84 \mathrm{~Bq} \mathrm{~kg}^{-1}\right)$. The ${ }^{210} \mathrm{~Pb}_{\mathrm{ex}}$ that was almost negligible in the moraine profiles was only detected in the topsoil of PB1 and at $10-20 \mathrm{~cm}$ in PB2. Therefore, the typical decay pattern of the FRNs mass activities with depth was not found in these moraine profiles.

The colluvium profiles of ${ }^{137} \mathrm{Cs}$ showed an exponential decrease with the depth. The decay was more marked in PB3 and PE1 profiles, the ${ }^{137} \mathrm{Cs}$ mass activities decreased sharply from the topsoil that had very high values $\left(266-346 \mathrm{~Bq} \mathrm{~kg}^{-1}\right)$ to low values in deeper layers $\left(1.64-2.75 \mathrm{~Bq} \mathrm{~kg}^{-1}\right)$. The mass activities of ${ }^{210} \mathrm{~Pb}_{\text {ex }}$ were considerably lower and the radionuclide was only found in the upper layers, therefore the penetration of ${ }^{210} \mathrm{~Pb}_{\text {ex }}$ was much lower than that of ${ }^{137} \mathrm{Cs}$ that was detected at $25 \mathrm{~cm}$ in PE1 (Fig. 6).

The depth distributions of ERNs showed different patterns, thus that of ${ }^{226} \mathrm{Ra}$ and ${ }^{232} \mathrm{Th}$ were very similar in the moraine profiles, but this was not the case in the colluvium profiles which even exhibited opposite trends in profile PE1. The ${ }^{40} \mathrm{~K}$ mass activities varied largely and values were higher in the profiles of Bødalen. The ${ }^{238} \mathrm{U}$ was the lesser variable, and it did not show any clear pattern in its depth distribution.

All profiles showed disequilibrium in the U-Th series. Under secular equilibrium the activity ratios of ${ }^{238} \mathrm{U} /{ }^{226} \mathrm{Ra}$ will be approximately 1 , and 1.1 for ${ }^{232} \mathrm{Th} /{ }^{226} \mathrm{Ra}$ (Evans et al., 1997). However, values in the profiles largely exceeded 1 
Moraines

PB1

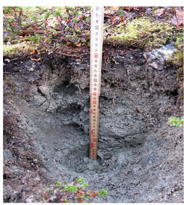

PB2

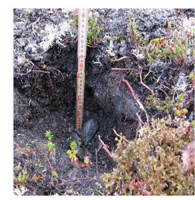

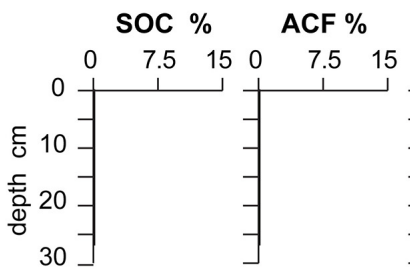

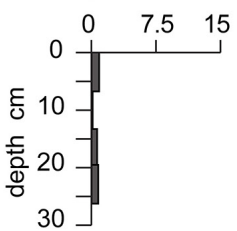

SCF \%
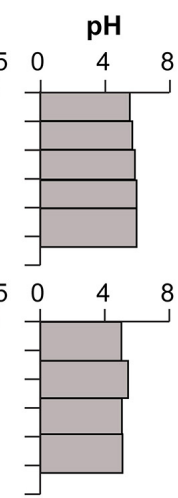

Grain Size \% Stones \%
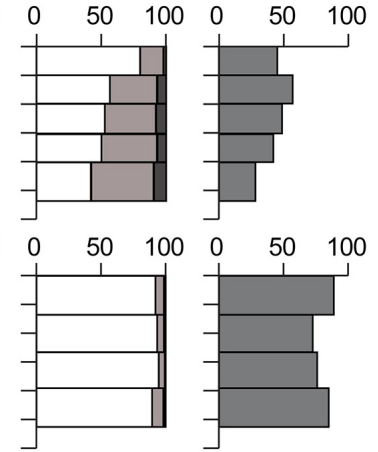

Colluvium
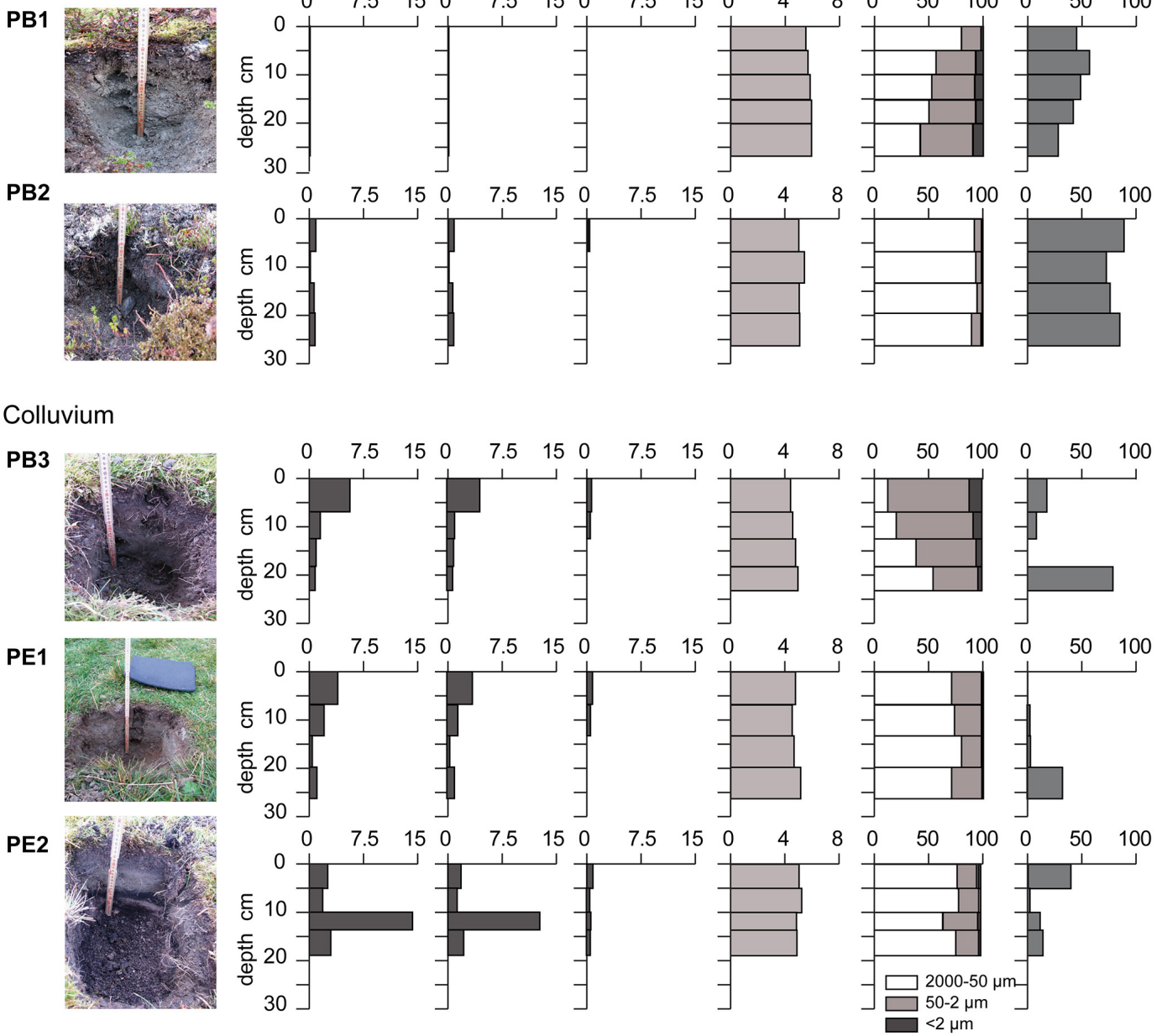

Figure 4. The study profiles on the Leptosols of the moraines and the Regosols of the colluvium and the depth distribution of main soil properties.

(range 1.27-2.98) and the colluvium profile PB3 showed the greater disequilibrium. Similarly, all soil profiles had ${ }^{232} \mathrm{Th} /{ }^{226} \mathrm{Ra}$ activity ratios higher than 1.1 . Deviations were much higher in profile PB3 (3.34-4.25) despite the depleted levels of ${ }^{232} \mathrm{Th}$ (Fig. 6) in topsoil layers of the colluvium profiles.

\section{Discussion}

On the colluvium the Regosols are better developed with a rich organic A horizon, whereas the Leptosols on the moraines are shallow and do not present horizon differentiation. The higher content of coarse fractions in the Leptosols is related to the original till parent material, but is also in accordance with the physical processes (such as rock disintegration by the action of ice) that are more important in the moraines than in the colluviums. This is likely because moraine materials have been subjected until very recently to ice action, but also because they are more exposed to physical disintegration, as moraines have less continuous vegetation cover than colluviums. These features result in distinctive soil properties that affect the pattern distribution of stable elements and radionuclides in the profiles. In spite of the fact that studies on the vertical distribution of elements in soils of cold regions are scarce, results from previous research in Maritime Antarctica (Navas et al., 2005a, 2008) have also evidenced the variation of FRN and ERN contents in relation to processes affecting soils in different morphoedaphic environments. Moreover, similar to what it was observed in the study valleys, the variability in some radionuclides and elements was also related to the mineral composition of parent materials and to cryogenic and soil processes influencing the depth distribution of soil properties, such as that of granulometric fractions and organic matter.

The type of relationship between stable elements (either direct or inverse) suggests common or different origins, respectively, from minerals contained in the granitic 


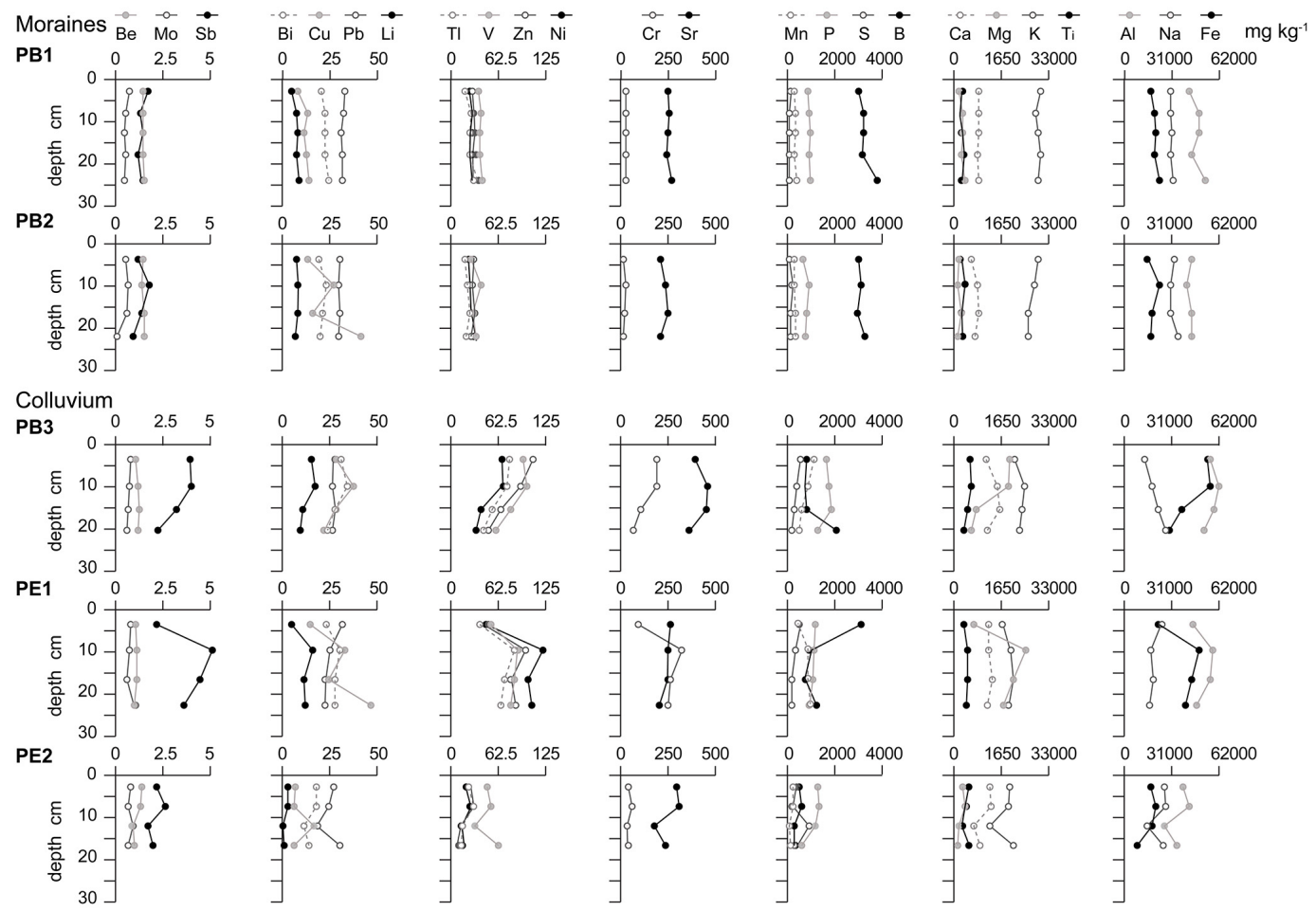

Figure 5. Vertical distribution of the chemical elements $\left(\mathrm{mg} \mathrm{kg}^{-1}\right)$ in the soil profiles on the moraines and colluviums.
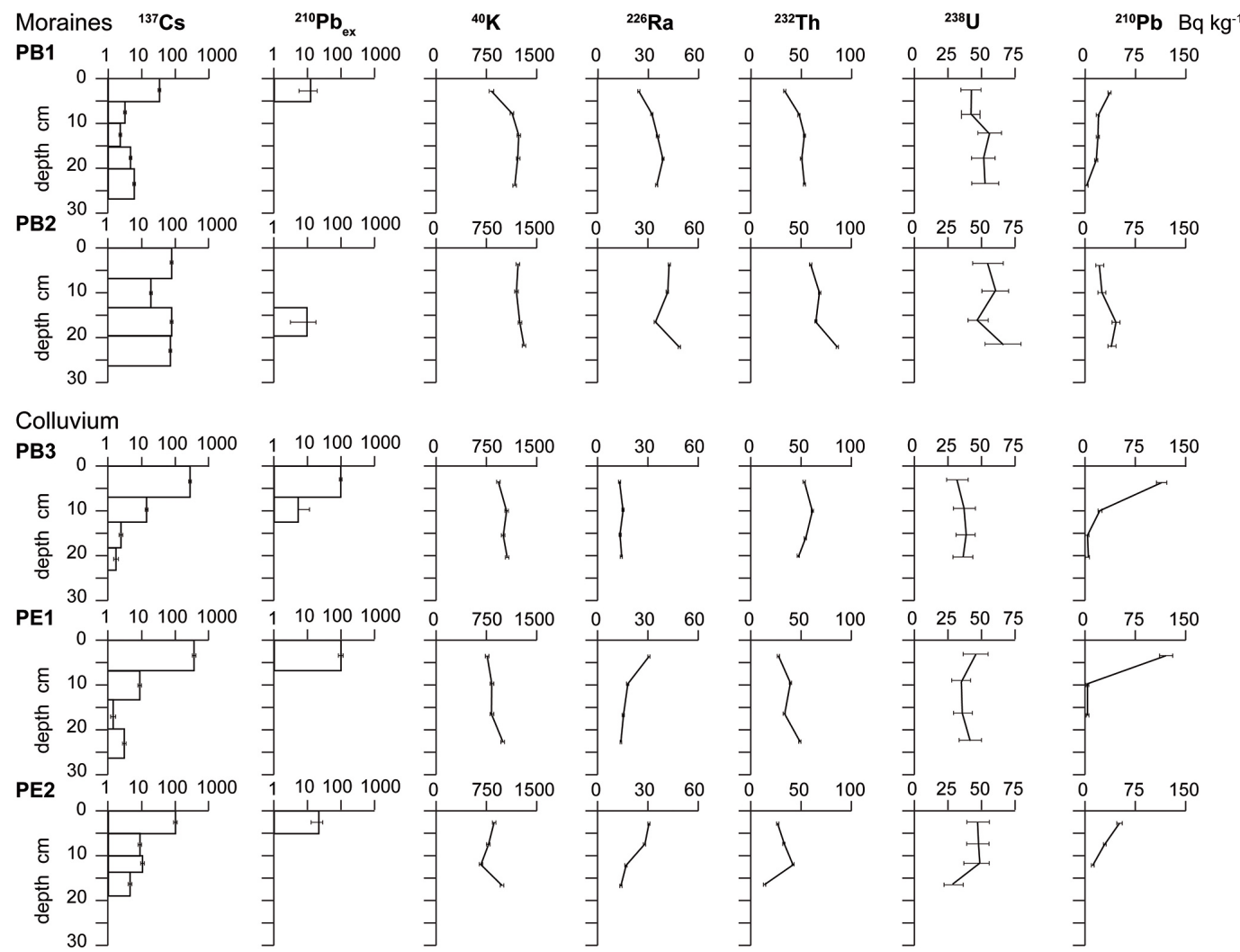

Figure 6. Depth distribution of the mass activities $\left(\mathrm{Bq} \mathrm{kg}^{-1}\right)$ of FRNs and ERNs in the soil profiles on the moraines and colluviums. 
orthogneisses, on which soils are developed. Furthermore, differences in the development of the study soils might have an influence on the elements and their abundance. Thus, elements present in Leptosols would reflect more closely the composition of parent materials than those in Regosols, which are more developed soils. This fact may also have an effect on element accumulation, as most elements present higher contents in Regosols than in Leptosols. High correlation coefficients between elements would indicate similar transport, accumulation and sources (Acosta et al., 2011). The inverse correlations found between $\mathrm{Na}, \mathrm{K}$, $\mathrm{Pb}$, and $\mathrm{Be}$ with the rest of elements and the direct correlations between them suggest different mineralogical sources. These elements, which are more abundant in Leptosols on the moraines, might be mainly derived from tectosilicates, whereas the rest of the elements likely originated from other types of silicates. Evidences of the main control of substrate mineralogy and on the element transfer from rock to soil were also found on a variety of substrates and environments (Wang and Chen, 1998; Navas et al., 2002c). Moreover, sharp decreases in the contents of most elements, apart from Mo, $\mathrm{Cu}$ and $\mathrm{S}$, are associated with the high increase of SOC content found at $10-15 \mathrm{~cm}$ depth in PE2, supporting the close links of most elements with the mineral contents.

The range of variation of ${ }^{137} \mathrm{Cs}$ and ${ }^{210} \mathrm{~Pb}_{\mathrm{ex}}$ is linked to the high contents recorded in the organic horizons of the Regosols of the colluviums, while the highest content of ERNs, in the Leptosols, apart from ${ }^{210} \mathrm{~Pb}$, is related to mineralogical and geochemical differences in the composition of the moraine materials. Significant positive correlations of ${ }^{137} \mathrm{Cs}$ with SOC and ACF contents and inverse correlations with $\mathrm{pH}$ and the silt and clay fractions found in Leptosols were not observed in the Regosols on the colluviums outside the LIA. Therefore, correlations among the radionuclides with the soil properties support the different characteristics of FRNs in the Leptosols of recently deglaciated moraines affected by LIA compared with the Regosols outside the LIA.

In the colluvium profiles the type of correlations that were similar for ${ }^{232} \mathrm{Th}$ and ${ }^{40} \mathrm{~K}$ suggest that both radionuclides are related with clay minerals, whereas the opposite was true for ${ }^{226} \mathrm{Ra}$ and ${ }^{238} \mathrm{U}$ which might indicate a common and different mineralogical source to that of ${ }^{232} \mathrm{Th}$ and ${ }^{40} \mathrm{~K}$. However, in the moraine profiles the type of correlations was different and not significant.

The direct and significant correlations among the ERNs in the moraine profiles denote a common origin (Fairbridge, 1972). However, the contrary was observed in the colluvium profiles, suggesting that soil processes in the more developed soils, either by accumulation of the radionuclides associated with fine minerals or due to differential mobility, have affected the distribution of ERNs. Thus ERNs are not as closely linked to their primary mineralogical origin as in the moraine profiles, where radionuclides might be internally bound in primary minerals as found by Nielsen and Murray (2008) in sandy sediments of Jutland (Denmark).
The higher values and decreasing distribution of SOC in Regosols illustrates a higher degree of soil evolution, reflecting the oldest age in terms of ice-free retreat of the colluvium sites that became deglaciated approximately 10000 years ago. This is further confirmed by the higher percentages of the SCF compared to its content in the moraine profiles. The SOC-rich layer at the $10-14 \mathrm{~cm}$ interval depth in PE2 (see Fig. 4) might correspond to a buried soil that is likely to have occurred at this site due to intense and frequent rockfall activity.

The grain size distribution in the profiles helps to interpret the role of physical processes such as rock disintegration on soil development in cold environments (Navas et al., 2008). In general, these soils are characterized by the abundance of sand content, especially in the topsoil. However, the low values and increasing contents of sand with depth in PB3 (see Fig. 4) are related to the decreasing trends in the contents of most elements, apart from $\mathrm{Na}$ and $\mathrm{B}$. This site, which is in a hillslope located beneath the Tindefjell glacier, is more influenced by glaciofluvial and outwash processes rather than rockfall activity that likely affects the particle size distribution in the profile. In addition, compared to the other sites, this site is more impacted through animal husbandry, as sheep grazing has taken place since approximately 1800 , but with lower intensity since 1930 .

The reason for the homogeneous vertical distribution of chemical elements in moraine profiles, rather than the larger variations observed in colluvium profiles (see Fig. 5), is the lack of horizon differentiation in the recently formed Leptosols on till material. Under the cold climate existing in the study valleys, soil processes are limited and slow, resulting in shallow and poorly developed soils with almost no horizon differentiation. The variations in the depth distribution of SOC and sand contents are related to the vertical distribution of the elements and are responsible for the contrasts observed between colluvial and moraine soil profiles. Furthermore, the geochemical variability found in the study profiles is linked with the parent materials and their mineralogical composition. In agreement with what was found by other authors in a variety of environments (e.g. Wang and Chen, 1998; Acosta et al., 2011), relationships between elements evidenced the key control of the mineralogy of the substrate on the element transfer from rock to soils.

The contrasting patterns between the vertical distribution of the mass activities of ${ }^{137} \mathrm{Cs}$ and ${ }^{210} \mathrm{~Pb}_{\mathrm{ex}}$ in the moraine and colluvium profiles are likely related to the different periods of ice retreat. Even for shorter periods, as in the case of moraine profiles, differences seen between the study profiles might be related to the age of ice retreat, as the lower FRN contents in PB1 (that is the less developed soil since the site became ice-free at ca. AD 1930) might suggest via comparison with PB2, which became ice-free earlier around AD 1800. Furthermore, the absence of the typical decay pattern of the FRN mass activities with depth in moraine profiles could be due to several reasons. The till material, the lack of 
horizon differentiation, and the predominance of coarse fractions in the soil matrix of the moraines may have favoured the rapid infiltration of water carrying the FRNs to deeper layers. In spite that some types of clays may be more efficient in the adsorption of the radionuclides (e.g. Staunton and Roubaud, 1997) especially in the frayed edge sites (Sawhney, 1972), the fixation of the FRNs by the organic matter that may inhibit that of clays is an efficient non-specific mechanism fixing ${ }^{137} \mathrm{Cs}$ and ${ }^{210} \mathrm{~Pb}_{\text {ex }}$ (Takenaka et al., 1998, Gaspar and Navas, 2013; Gaspar et al., 2013). Therefore, the very low content of SOC in the moraine profiles would also contribute to the low fixation of the FRNs. Another reason may be the cryogenic processes and the disturbance of soil by the ice action, which in the moraine sites can be more intense than in the colluviums. Meanwhile, the high values of ${ }^{137} \mathrm{Cs}$ mass activity in the topsoil of the exponential decay profiles in colluvium soils is likely because of the influence of the Chernobyl accident in 1986 (Gjelsvik and Steinnes, 2013).

In relation to the depth distributions of ERNs, the larger variability of ${ }^{226} \mathrm{Ra}$ and ${ }^{232} \mathrm{Th}$ in this environment can be explained by the lack of carbonates as opposed to those observed in Mediterranean carbonate-rich soils, where high carbonate contents restricted the mobility of these radionuclides (Navas et al., 2002a, b). The depleted levels of ${ }^{40} \mathrm{~K}$ at the topsoil of PB1 are related to lower contents in clay and silt fractions. As it is widely known in the literature (e.g. Jasinska et al., 1982, Baeza et al., 1995, VandenBygaart and Protz, 1995), the environmental radionuclides are associated with clay minerals or they are fixed within the lattice structure. The significantly higher values of ${ }^{40} \mathrm{~K}$ in the profiles of $\mathrm{B} \varnothing-$ dalen are likely related to differences in mineralogical composition, which can be further confirmed by its sharp depletion in the rich organic layer of PE2. Baeza et al. (1995) indicate that radioactivity increases as particle size decreases. In Antarctica, profile increases in clay contents were paralleled with ERN enrichments (Navas et al., 2005a). In general, bedrock composition appears to be the main factor of variation of the ERNs in the study profiles.

Although most environmental samples have ${ }^{232} \mathrm{Th} /{ }^{226} \mathrm{Ra}$ activity ratios around 1.1 (Evans et al., 1997) and ${ }^{238} \mathrm{U} /{ }^{226} \mathrm{Ra}$ ratios are approximately 1 under secular equilibrium, all soil profiles deviated from these values, indicating disequilibrium in the uranium and thorium series. Disequilibrium can be due to the active hillslope processes such as intense outwash processes and rockfall. Besides, differential mobility of the radionuclides (e.g. Collerson et al., 1991) may have also had an influence. Harmsen and de Haan (1980) indicate that $\mathrm{U}$ and $\mathrm{Th}$ form hydrated cations $\left(\mathrm{UO}_{2}^{2+}, \mathrm{Th}^{4+}\right)$ that are easily mobilized over a broad range of soil $\mathrm{pH}$ from less than 4 to 9 .

In spite of differences with the climatic conditions existing in the southern circumpolar region, processes of soil formation similar as those operating in extreme cold regions (Bockheim and McLeod, 2006) can be expected to affect the areas recently deglaciated in the upper Erdalen and Bødalen val- leys. Thus, in the LIA moraines (and especially in the areas that became ice-free in the past century) the role of freezethaw and wetting and drying cycles seems to be more important than other weathering mechanisms. In cold regions such as in Antarctica, freeze-thaw weathering is generally recognized to be the most important process, causing rock disintegration and soil formation (Serrano et al., 1996, Hall 1997; Navas et al., 2008). However, in the areas outside the LIA influence, where the colluvium profiles are located physical processes, as rockfall, glaciofluvial and outwash processes and chemical weathering are main soil-forming processes.

\section{Conclusions}

The higher horizon differentiation in the more evolved Regosols developed on colluvium, in comparison to the Leptosols on the moraines, determine the larger variability in the elemental composition down the Regosol profiles. Radionuclide activities in the soils differed as a function of the characteristics of geomorphic elements and the processes occurring on the different geomorphic elements and substrates that have became ice-free at different ages. The distribution of ENRs is linked to the mineral composition of the parent materials. Geomorphic and soil processes that trigger the enrichment of the fine fractions containing sheet silicates determine the abundance of ${ }^{40} \mathrm{~K}$ and ${ }^{232} \mathrm{Th}$, whereas ${ }^{238} \mathrm{U}$ and ${ }^{226} \mathrm{Ra}$ are rather associated to minerals included in coarser fractions. In this environment the transference of the radionuclides and elements down the profile might be time restricted to the periods in which water circulates down the soil profile, which can further influence the differences in soil processes found between colluvium and moraine profiles.

In cold regions, such as the one in this study, information on the period of ice retreat could be derived by the pattern distribution of FRNs, as the typical decay pattern of FRN mass activities with depth is not found in moraine profiles of the LIA compared to the typical decay patterns found in more evolved soils of the colluviums that were deglaciated around 10000 BP. In addition, other soil properties can be combined to discern the main geomorphic processes related to the ice age retreat.

Acknowledgements. Financial support from CICYT project EROMED (CGL2011-25486/BTE) is gratefully acknowledged. Fieldwork in Erdalen und Bødalen was funded by the SedyMONTNorway project (Norwegian Research Council NFR, grant 193358/V30 to A.A. Beylich).

Edited by: P. Pereira 


\section{References}

Acosta, J. A., Martínez-Martínez, S., Faz, A., and Arocena, J.: Accumulations of major and trace elements in particle size fractions of soils on eight different parent materials, Geoderma, 161, 3042, 2011.

Appleby, P. G. and Oldfield, F.: Application of lead-210 to sedimentation studies, in: Uranium-series disequilibrium: Applications to earth, marine, and environmental sciences, edited by: Ivanovich, J. and Harman, R. S., Clarendon Press, Oxford, United Kingdom, 731-738, 1992.

Baeza, A., del Río, M., Jiménez, A., Miró, C., and Paniagua, J.: Influence of geology and soil particle size on the surfacearea/volume activity ratio for natural radionuclides, J. Radioanal. Nucl. Ch., 189, 289-299, 1995.

Beylich, A. A. and Laute, K.: Spatial variations of surface water chemistry and chemical denudation in the Erdalen drainage basin, western Norway, Geomorphology, 167-168, 77-90, 2012.

Bickerton, R. W. and Matthews, J. A.: Little Ice Age variations of outlet glaciers from the Jostedalsbreen ice-cap, southern Norway: a regional lichenometric-dating study of ice-marginal moraine sequences and their climatic significance, J. Quaternary Sci., 8, 45-66, 1993.

Bockheim, J. G. and McLeod, J. G.: Soil formation in Wright Valley, Antarctica since the late Neogene, Geoderma, 137, 109-116, 2006.

Collerson, K. D., Gregor, D. J., McNaughton, D., and Baweja, A. S.: Effect of coal dewatering and coal use on the water quality of the East Poplar River, Saskatchewan. A literature review. Inland Waters Directorate, Environment Canada, Scientific Series, No. 177, 1991.

Evans, C. V., Morton, L. S., and Harbottle, G.: Pedologic assessment of radionuclide distributions: use of a radio-pedogenic index, Soil Sci. Soc. Am. J., 61, 1440-1449, 1997.

Fairbridge, R. W.: The encyclopedia of geochemistry and environmental sciences, edited by: Van Nostrand, R., Van Nostrand Reinhold Co, New York, vol. 4A, 1215-1228, 1972.

Gaspar, L. and Navas, A.: Vertical and lateral distributions of ${ }^{137} \mathrm{Cs}$ in cultivated and uncultivated soils on Mediterranean hillslopes, Geoderma, 207-208, 131-143, 2013.

Gaspar, L., Navas, A., Machín, J., and Walling, D. E.: Using ${ }^{210} \mathrm{~Pb}_{\mathrm{ex}}$ measurements to quantify soil redistribution along two complex toposequences in Mediterranean agroecosystems, northern Spain, Soil Till. Res., 130, 81-90, 2013.

Gjelsvik, R. and Steinnes, E.: Geographical trends in ${ }^{137}$ Cs fallout from the Chernobyl accident and leaching from natural surface soil in Norway, J. Environ. Radioactiv., 126C, 99-103, 2013.

Hall, K.: Rock temperatures and implications for cold region weathering. I: New data from Viking Valley, Alexander Island, Antactica, in: Permafrost Periglac. Proc., vol. 8, 69-90, 1997.

Harmsen, K. and de Haan, F. A, M.: Occurrence and behavior of uranium and thorium in soil and water, Neth. J. Agr. Sci., 28, 40-62, 1980.

Jasinska, M., Niewiadomski, T. and Schwbenthan, J.: Correlation between soil parameters and natural radioactivity, in: Natural radiation environment, edited by: Vohra, K., Mishra, U. C., Pillai, K. C., and Sadasivan, S., John Wiley and Sons, New York, 206211,1982
Laute, K. and Beylich, A. A.: Influences of the Little Ice Age glacier advance on hillslope morphometry and development in paraglacial valley systems around the Jostedalsbreen ice cap in Western Norway, Geomorphology, 167-168, 51-69, 2012.

Laute, K. and Beylich, A. A.: Holocene hillslope development in glacially formed valley systems in Nordfjord, western Norway, Geomorphology, 188, 12-30, 2013.

Laute, K. and Beylich, A. A.: Morphometric and meteorological controls on recent snow avalanche distribution and activity at hillslopes in steep mountain valleys in western Norway, Geomorphology, 218, 16-34, 2014.

Lopez-Capel, E., Krull, E. S., Bol, R., and Manning, D. A. C.: Influence of recent vegetation on labile and recalcitrant carbon soil pools in central Queensland, Australia: evidence from thermal analysis quadrupole mass spectrometry-isotope ratio mass spectrometry, Rapid Commun. Mass Sp., 22, 1751-1758, 2008.

Lutro, O. and Tveten, E.: Bedrock map ÅRDAL M $1: 250.000$. Norges geologiske unders $\varnothing$ kelse, Trondheim, 1996.

Matthews, J. A., Shakesby, R. A., Schnabel, C., and Freeman, S.: Cosmogenic ${ }^{10} \mathrm{Be}$ and ${ }^{26} \mathrm{Al}$ ages of Holocene moraines in southern Norway I: testing the method of confirmation of the date of the Erdalen event (c. $10 \mathrm{ka}$ ) at its type site, Holocene, 18, 11551164, 2008.

Mavlyudov, B. R., Savatugin, L. M., and Solovyanova, I. Yu.: Reaction of the Glaciers of Nordenskiold Land (Spitsbergen archipelago) on climate change, Problems of Arctic and Antarctic, 1 (91), AARI, Sankt-Petersburg, 67-77, 2012 (in Russian).

Navas, A., and Machín, J.: Spatial distribution of heavy metals and arsenic in soils of Aragón (northeast Spain): controlling factors and environmental implications. Appl.Geochem., 17, 961-973, 2002c.

Navas, A., Soto, J., and Machín, J.: Edaphic and physiographic factors affecting the distribution of natural gamma-emitting radionuclides in the soils of the Arnás catchment in the Central Spanish Pyrenees, Eur. J. Soil Sci., 53, 629-638, 2002a.

Navas, A., Soto, J., and Machín, J.: ${ }^{238} \mathrm{U},{ }^{226} \mathrm{Ra},{ }^{210} \mathrm{~Pb},{ }^{232} \mathrm{Th}$ and ${ }^{40} \mathrm{~K}$ activities in soil profiles of the Flysch sector (Central Spanish Pyrenees), Appl. Radiat. Isotopes, 57, 579-589, 2002b.

Navas, A., Soto, J., and López-Martínez, J.: Radionuclides in soils of Byers Peninsula, South Shetland Islands, Western Antarctica, Appl. Radiat. Isotopes, 62, 809-816, 2005a.

Navas, A., Soto, J., and Machín, J.: Mobility of natural radionuclides and selected major and trace elements along a soil toposequence in the central Spanish Pyrenees, Soil Sci., 170, 743-757, 2005 b.

Navas, A., López-Martinez, J., Casas, J., Machín, J., Durán, J. J., Serrano, E., Cuchí, J. A., and Mink, S.: Soil characteristics on varying lithological substrates in the South Shetland Islands, maritime Antarctica, Geoderma, 144, 123-139, 2008.

Nesje, A.: Kvartærgeologiske undersøkningar i Erdalen, Stryn, Sogn og Fjordane, M. Sc. thesis, University of Bergen, 201 pp., 1984.

Nielsen, A. H and Murray, A. S.: The effects of Holocene podzolisation on radionuclide distributions and dose rates in sandy coastal sediments, Geochronometria, 31, 53-63, 2008.

Sawhney, B. L.: Selective adsorption and fixation of cations by clay minerals: a review, Clay. Clay Miner., 20, 93-100, 1972.

Serrano, E., Martínez de Pisón, E., and López-Martínez, J.: Periglacial and nival landforms and deposits, in: Geomorpholog- 
ical map of Byers Peninsula, Livingston Island, edited by: LópezMartínez, J., Thomson, M. R. A., and Thomson J. W. BAS Geomap Series 5-A. British Ant Surv, Cambridge, 15-19 pp. 1996.

Serrano, E. and López-Martínez, J.: Rock glaciers in the South Shetland Islands, Western Antarctica, Geomorphology, 35, 145-162, 2000.

Staunton, S. and Roubaud, M.: Adsorption of ${ }^{137}$ Cs on montmorillonite and illite: effect of charge compensanting cation, ionic strength, concentration of $\mathrm{Cs}, \mathrm{K}$ and fulvic acid, Clay Clay Miner., 45, 251-260, 1997.

Takenaka, C., Onda, Y., and Hamajima, Y.: Distribution of cesium 137 in Japanese forest soils: correlation with the contents of organic carbon, Sci. Total Environ., 222, 193-199, 1998.
Van Cleef, D. J.: Determination of ${ }^{226} \mathrm{Ra}$ in soil using ${ }^{214} \mathrm{~Pb}$ and ${ }^{214} \mathrm{Bi}$ inmediately after sampling, Health Phys., 67, 288-289, 1994.

VandenBygaart, A. J. and Protz, R.: Gamma radioactivity on a chronosequence, Pinery Provincial Park, Ontario, Can. J. Soil Sci., 75, 73-84, 1995.

Wang, X. J. and Chen, J. S.: Trace element contents and correlation in surface soils in China's eastern alluvial plains, Environ. Geol., 36, 277-284, 1998.

Winkler, S., Elvehøy, H., and Nesje, A.: 2009: Glacier fluctuations of the Jostedalsbreen, western Norway, during the past 20 years: the sensitive response of maritime mountain glaciers, Holocene, 19, 395-414, 2009. 